\title{
Eestikeelse termini kõnekäänd kujunemislugu ${ }^{1}$
}

\author{
Anneli Baran \\ Eesti Kirjandusmuuseumi folkloristika osakonna vanemteadur \\ anneli@folklore.ee
}

\begin{abstract}
Teesid: Ütlusfolkloori esindavad kõnekäänud kuuluvad iga keele koosseisu. Nende abil on võimalik rikastada nii suulist kui ka kirjalikku keelt, oskus selliseid keelendeid kasutada annab tunnistust keele valdamisest. Kujundkeele ilminguid märkiv termin kõnekäänd ilmus eesti keelde esmakordselt paarsada aastat tagasi. Käesolevas artiklis võetakse vaatluse alla eesti keele kirjalikud allikad (sõnastikud, grammatikad, õpikud, käsiraamatud, monograafiad, aga ka kirjavahetused, käsikirjalised kogud) 17. sajandist kuni 1920. aastateni, selgitamaks välja, kuidas see oskussõna tekkis ja millised olid kasutuselevõtu põhjused. Seejuures antakse ka sissevaade saksa keeles käibel olnud terminoloogiasse, osutamaks muukeelsete mõjude osatähtsusele tookordsele, alles kujunevale kirjakeelele.
\end{abstract}

Märksõnad: kirjakeel, kõnekäänd, saksa keel, sõnaraamat, vanasõna, õpikud, ütlusfolkloor

\section{Sissejuhatuseks}

Varasemates uurimistöödes on vaadeldud rahvaluule ütlusfolkloori - vanasõnade, kõnekäändude - publitseerimise ajalugu (Sarv 1964) ning fraseoloogia käsitlusi 20. sajandil (Õim \& Õim 2011). Samuti on käsitletud mitmel korral kõnekäänu ja fraseologismi eritlemisega seotud raskusi (Baran 1998; Krikmann 1997; Õim 2005). Neis kirjutistes tuleb selgelt esile rahvaluule lühivormide omavaheline tihe seostumine ja iseäranis vanasõnast erinevate rahvapäraste ütluste žanriline iseseisvusetus, mis põhjustab klassifitseerimisraskusi ja terminoloogilist segadust. Käesolevas artiklis keskendutakse eelkõige eestikeelse fraseoloogia terminoloogia ajaloolisele kujunemisele rõhuasetusega kõnekäänuterminil, alates varaseimatest kirjakeele allikatest kuni 1920. aastatel ilmunud trükisteni.

Eesti keeles on pikka aega tavatsetud kasutada püsivate kujundlike ütluste kohta termineid vanasõna, kõnekäänd, fraseologism. Piiritlemine võib erisustele 
vaatamata olla äärmiselt keerukas. Võib siiski sõnastada üldprintsiibi, mis võimaldab teha vahet vanasõnadel ja muudel ütlusfolkloori ilmingutel - kui vanasõnad on oma olemuselt üldistavad, siis püsiväljendid on üksikjuhtude kujundlikud iseloomustused (vt Krikmann 1997: 52-53). Samas on viimaste kogum sedavõrd mitmekesine, et võimaldab erisugust lähenemist, mis sõltub suuresti sellest, kas materjali käsitletakse lingvistilisest või folkloristlikust vaatepunktist (Õim 2005: 209).

\section{Püsiväljendeid märkivatest terminitest vanimas kirjasõnas}

Rääkides vanimatest eestikeelsetest oskussõnadest, ei saa mööda vaadata eesti keele varasemat arengut tugevalt mõjutanud saksa keelest. Eesti keele ning ühtlasi ka rahvaluuletekstide varaseimates allikates ei kasutata rahvakeelsete väljendite nimetusena eestikeelseid termineid. Enamasti tuuakse eestikeelsete näitetekstide loendid ära võõrkeelsete pealkirjade all. Seda põhjusel, et vanemate väljaannete koostajateks olid enamasti saksa päritolu kirikuõpetajad, kelle emakeel oli saksa keel. Saksa keeles on seesuguste ütluste kohta olnud sajandeid kasutusel kaks paralleelset terminit: die Redensart ja die Redewendung. Kui esimene kõlab otsetõlkes kui 'kõne(lemise) viis' (Muuk \& Tuksam 1941), siis teist terminit saaks tõlkida 'kõne pööre', võttes aluseks saksakeelse verbi wenden tähenduse 'pöörama, ümber pöörama' (Kibbermann \& Kirotar \& Koppel 2007). Kuigi mõlemad terminid on alates nende kasutuselevõtust püsinud keeles kõrvuti, on Redensart olnud läbi aegade siiski tunduvalt eelistatum. See traditsioon on säilinud saksa keeles tänaseni.

Termin Redensart pärineb 17. sajandi algusest Johannes Arndti teosest "Vom wahren Christenthumb" (1610) ning seda laenuna prantsuse keelest: façon de parler 'kõnelemise viis'. Teine saksakeelses teaduskirjanduses samas tähenduses tuntud oskussõna Redewendung (lühendatult die Wendung) on mõnevõrra hilisem, kuid pärit samuti 17. sajandist: saksa fraseoloogi Wolfgang Fleischeri andmetel aastast 1691 (Fleischer 1997: 3). Kuigi Fleischer ei too välja allikat ennast, on selleks täpsustatud andmetel Kaspar von Stieleri sõnaraamat "Der teutschen Sprache Stammbaum und Fortwachs", kus see on esitatud järgmiselt: Wendung > Redewendung / paraphrasis (1691: 2500). Kahe termini suurim erinevus on neist ühe tugev seostamine vanasõnaga. Tuletis sprichwörtliche Redensart 'vanasõnaline kõnelemisviis' esineb esmakordselt 1663. aastal ning selleks allikaks on oma aja silmapaistvaimaks saksa keele grammatikaks peetav Justus Georg Schotteli "Ausführliche Arbeit Von der Teutschen HaubtSprache”. Tänapäevalgi saksa keeles tuntud termin levis ja 
saavutas populaarsuse märksa hiljem, täpsemalt 19. sajandil, nagu nähtub tollal ilmunud tuntumatest tekstikogumikest (Seiler 1922).

Kõrvuti nende kahe omakeelse terminiga on vanemas saksakeelses kirjanduses kujundlike väljendite tähistamiseks vähesel määral kasutatud ka prantsuse keele kaudu 17. sajandil laenatud sõna die Phrase 'fraas'. Lisaks algsele tähendusele - mittelauselise ehitusega sõnade järjend ehk lause moodustaja omandas see termin saksa keeles varakult ka pejoratiivse lisatähenduse '(sisu) tühi väljendus', mis muutus kiiresti üldiseks (Fleischer 1997: 2-4). ${ }^{3}$

Eesti vanimates kirjakeele allikates kasutatakse rahvapäraste ütluste kohta kas ladinakeelset üldnimetust Proverbium/Proverbia 'vanasõna(d)'4 või saksakeelset terminit das Sprichwort ('vanasõna', otsetõlkes 'räägitud sõna'; vt ka Schulze 1851: 377). Kui üldse kohtab nende kahe kõrval mõnd muud terminit, siis on selleks die Redensart.

Eestikeelse fraseoloogia esmaseks esinemiskohaks saab olemasolevate andmete alusel pidada Georg Mülleri käsikirjalisi jutlusi (vt Krikmann 1992). Esmakordseks trükis ilmumise kohaks aga eesti keele olulisemaid varaseimaid publikatsioone: Heinrich Stahli “Anführung zu der Ehstnischen Sprach” (1637) ja Heinrich Gösekeni "Manuductio ad Linguam Oesthonicam, Anführung zur Öhstnischen Sprache" (1660).

Stahli teos sisaldab kujundliku keele näiteid, kuid mitte termineid. Stahl toob märksõna Rede 'kõne' ja verbi reden vastega 'kõnelema', selgitamata aga nende kasutust lähemalt. Nii ei leidu Stahlil ka näiteks saksakeelset terminit Redensart, mis selleks ajaks oli saksa keeles juba olemas.

Küll esineb selles saksa-eesti sõnastiku osas saksakeelse Sprichwort vastena Wanna Sanna. Tähendusseletusena toob ta seejuures üksnes napi lihckpajatus. 1637. aastal trükivalgust näinud Stahli käsiraamatu "Hand und Hausbuch für das Fürstenthumb Esthen In Lifland" teisest osast leiab vanasõna-termini koos eestikeelse kasutusnäitega: Iggal asjal oma aick üx wanna sanna on (Habicht \& Penjam \& Prillop 2015: 412). Kuidas tuleks aga mõista sõnastikus toodud vanasõna järel olevat liitsõna? Kuna verb pajatama esineb Stahlil saksa sprechen vastena koos tähendusega 'lausuma', siis selle tuletis pajatus on ootuspärane ${ }^{5}$, küll on aga keerukam välja selgitada sellest lichk- esiosisega moodustatud liitsõna tähendust. Üks võimalik tõlgendus oleks viide teistlaadsele rääkimisviisile. ${ }^{6}$ Paul Ariste on sama sõna tuvastanud ka Mülleri jutlustes ning määratlenud selle alamsaksa laenuna, kus esiosis kannab tähendust 'sarnane, võrdne' ning liitsõna tähenduseks on 'võrdlus, tähendamissõna' (Ariste 1981: 114). Samas tähenduses on just varasemates saksakeelsetes teostes kasutatud aga sõna Sprichwort (Schulze 1851: 377).

Göseken kasutab oma käsiraamatus ladinakeelset sõna Proverbium, märkimaks vanasõnu. Need esitab ta näidetena sõnaraamatu erinevate märksõnade 
juures. Samas kasutab ta ka saksakeelset Sprichwort, eelkõige just seostatuna rahvakeelega. Näiteks tähendusselgituses märksõna Teutscher juures: geringer (halb)Teutscher / kadaka (pohl) saks. NB. Schimpfliche Sprichwörter der Bauren von den Teutschen [talupoegade teotavad vanasõnad sakslastest - siinkirjutaja tõlge]. Sõnastikust leiab ka eestikeelse vanasõna ning seda sarnaselt Stahli esitatule, s.t seostatuna pajatamisega: Sprichwort (proverbium) $=$ wanna sanna / lihck paiatus. Viimase liitsõna leiab ka märksõna Gleichnis alt: 'lihck paiatus, tehhendaminne'. Esineb ka sõna Redeart (formula dicendi) selgitusega 'ninda rehckitaxe, oigte wihsi rehcki', mis osutab lähtekeelele sarnaselt kõnelemisviisile.

Stahli ja Gösekeni teoste ilmumisaja vahele jääb veel üks keelealane teos, Johannes Gutslaffi grammatika "Observationes grammaticae circa linguam Esthonicum” (1648), mis sisaldab vaid vähesel määral kujundlikke keeleüksusi. Tähelepanuväärselt kasutab autor aga peatükis "Süntaks" metafoori terminit - nimelt rääkides metafoorsetest nimetustest, mille koosseisu kuuluvaid artikleid peab ta metafoori tunnuseks (näit ütz Töppras, ütz öigke Töppras) (Gutslaff 1998: 189).

Eesti rahvaluule lühivormide esimeseks tähelepanuväärsemaiks allikaks võib eelmainitud trükiste kõrval pidada aga hoopis üht käsikirjalist materjali, milleks on Salomo Heinrich Vestringi eesti-saksa sõnaraamat "Lexicon Esthonicum Germanicum" (koostatud u 1710-1720, täiendatud 1740, trükis 1998). Leksikonist leiab märksõnade juures tooduna rikkalikult maarahva murdesõnavara, sh ka vanasõnu, piltlikke väljendeid jmt. ${ }^{7}$ Paraku ei kohta selles taolisi keelenähtusi tähistavat eestikeelset terminoloogiat. Eelmainitud pajatama ja pajatus sisalduvad küll ka Vestringi käsikirjas, aga saksakeelsete vastetega 'sprechen, reden' ja 'eine Rede' (seejuures märkusega obsol., mis on lisatud küll käsikirja anonüümse toimetaja poolt). Sealsamas toob Vestring nii Stahlil kui Gösekenil esinenud noomeni liig pajatus, esitades selle tähendusseletusena aga 'eine unnütze rede Lügen', mis osutab küll rääkimisele, aga samastades seda valetamisega. ${ }^{8}$ Sealjuures seostab Vestring seda rahvaliku keelekasutusega, võrdsustades liigse rääkimise ja valetamise: Se on rahwa liig pajatus 'Das haben die Leute gelogen' (Vestring 1998: 170). Huvitaval kombel ühitab Vestring ka mõiste kõne peaasjalikult tarbetu suupruukimisega nagu võib järeldada esitatud näidete põhjal: "Sel könnel ei olle hända tagga. Hännatumad Könned. Lapsed woiwat kaswata kül Könnet" (ibid.: 86). Eestikeelse wanna sanna leiab Vestringilt märksõna wannanema alt. Seejuures toob ta saksa vastena sõnaühendi Ein Altes Sprichwort, mis otsetõlkes kõlaks 'vana vanasõna'. ${ }^{9}$

Varasematest publikatsioonidest on silmapaistvaim Anton Thor Helle käsiraamat "Kurtzgefaszte Anweisung zur Ehstnischen Sprache" (1732). Nagu on märkinud Arvo Krikmann: "Eesti parömioloogilise allikaloo vanima perioodi 
võib jaotada kaheks: esimesest algusest Helleni ja Hellest Wiedemannini" (1986: 73). Helle teost saab kahtlemata pidada eestikeelse paröömika kujunemisloos oluliseks verstapostiks. Selles teoses sisaldub lisaks grammatikale ja sõnastiku osale ka loend, mis kannab pealkirja "Proverbia Esthonica oder Ehstnische Sprüch-Wörter". See koosneb ühtekokku 525 vanasõnalisest ja kõnekäänulisest üksusest. Erna Normanni andmetel (1959: 37) on neist kõnekäänuna määratletavad 112 teksti, Krikmann (1986: 73) märgib vanasõnahulgaks ligikaudu 420 teksti, mis teeb muude üksuste koguarvuks 105. Sama materjali leiab pea viiskümmend aastat hiljem ka August Wilhelm Hupeli grammatikast "Ehstnische Sprachlehre für beide Hauptdialekte" (1780), kuna Hupel toetus teadaolevalt suuresti Helle kogutule. Ka selles raamatus leidub omaette peatükk pealkirjaga "Ehstnische Sprüchwörter"10. Samuti leidub mõlema teose eesti-saksa sõnaraamatu osas märksõna wanna sanna ja selle vastena saksakeelne Sprüchwort. Erinevalt Hellest sisaldub Hupeli väljaandes ka saksa-eesti sõnastik. Selles annab ta saksakeelsele terminile Sprichwort eesti keeles kaks vastet: 'wanna sönna, moistu könne'. Vanasõna kõrval leidub Hupelil veel lihtsõna Spruch, mida ta seostab üheselt piibliga, märkides vaid saksa keeles biblisch, ehk siis saksa traditsioonile vastavalt. Vanasõnast teistlaadseid ütlustekste märkivat eestikeelset terminit nii Hellel kui Hupelil ei kohta, kuigi nii vanasõnapeatükis toodute kui ka sõnastiku keelenäidete seast leiab rohkelt vanasõnast erinevaid kujundlikke väljendeid (näiteks: egga mul ei olle ennam kui kaks kätt; vesi ahjus; ma räägin kuhja, sa räägid kuhja aeda; mul on silmad häbi täis).

Mõlemas teoses on leidnud koha aga üks huvitav sõnapaar: käänid ja vä̈̈nid 'Ausflüchte' (sks die Ausflucht 'põige, ettekääne' (Muuk \& Tuksam 1941)). Tegelikult esineb see juba Vestringil, mis kinnitab arusaama, et Helle (ja tema kaudu omakorda Hupel) ammutas rahvapärast keeleainest just sellest käsikirjast (Krikmann 1986). Erinevalt Hellest leidub Hupeli sõnaraamatu saksa-eesti pooles nimetatud fraasi juures küll mõnevõrra pikem selgitus. Nimelt toob ta märksõna Ausflüchte juures eesti vastena lisaks mainitud sõnapaarile veel noomeni liig könne ja ühendi ärrä käändlema sönnu, pidades kumbagi pigem tartu keelele iseloomulikuks. Ka esitab Hupel saksakeelse märksõna das Wort ('sõna') juures ühendi Worte verdrehen tähenduses 'sönna ümbre käändma'. Paraku jääb siinkohal selgusetuks, kas ta pidas seesuguse keelelise tegevuse all silmas pelgalt lõunaeesti murdekeeles kõnelemist või ka kujundlike keeleilmingute kasutust. Hupel toob märksõna Rede eestikeelse vastetena kõne, pajatus, ning ka juba Stahlil, Gösekenil ja Vestringil esinenud liitsõna liig pajatus. Sealsamas esitab ta, sarnaselt Vestringile, ka verbiühendi unnütze Rede führen, küll lisades tähendusselgituse 'sorrima' (Vestringil ka kujul takka sorrima). Kuna selle sõna saksakeelse vastena tuuakse leksikonis plaudern ehk 'lobisema' ning samasugust vastendamist kohtab lisaks Vestringile juba Göse- 
kenil, kinnitab see seik, et esmalt Mülleril ja Stahlil esinenud verbi pajatama ja sellest tuletatud liitsõna liigpajatus tähendused olid järgnevates väljaannetes muutunud, märkides pigem teistsugust rääkimisviisi.

Hupeli grammatikas sisaldub aga ka peatükk pealkirjaga "Von etlichen Idiotismen", milles ta võtab vaatluse alla sõnaühendid, mida olevat võimalik omandada üksnes sõnaraamatu abil. Saksakeelne Idiotismus on vananenud keeletermin tähistamaks väljendeid, mis on omased ühele kindlale piirkonnale ning mis pole teise keelde sõnasõnalt tõlgitavad, kuna nad on ebareeglipärased (Gottsched 1762: 538). Selliste keelendite näidetena tavatseti tollases saksakeelses kirjanduses tuua ka vanasõnu ja kõnekäände. Samamoodi räägib ka Hupel eestlaste kõnepruuki kuuluvatest ja üksnes eesti keelele omastest keeleilmingutest, mainides sõnade ja sõnaühendite kõrval ka pikemaid üksusi, mida märgib sõnaga die Redensarten (tuues näitena kes jummal sedda teab, pääw pääwalt, pääv lähhäb loja). ${ }^{11}$ Erinevalt lühivormide uurijast Ingrid Sarvest (1964) ei pea siinkirjutaja seda sõna Hupeli kasutuses kitsalt kujundlikku väljendit märkivaks terminiks, kuna selle sage kasutus mitte ainult ühes peatükis, vaid läbivalt kogu grammatikas osutab pigem erisugustele tähendustele (kõneviis, fraas, lause).

Samast ajajärgust pärinevad ka Johann Christoph Clare eesti-saksa sõnaraamatu käsikirjad (1730-34), milles sisalduv materjal pärineb aga peaasjalikult mingist tollasest laiemalt levinud tundmatust käsikirjast (koostajaks nn kristlik sõber, kellelt saadut leidub ka Hellel ja Vestringil) (Normann 1959: 37). Antud käsikirja tartukeelne materjal sisaldub pea tervenisti ka Hupeli grammatikas.

\section{Masing ja termin kõnekäänd}

Möödus tervelt 36 aastat, enne kui Otto Wilhelm Masing toob saksa päritolu pastoritele eesti keele õppevahendina mõeldud brošüüris "Ehstnische Originalblätter für Deutsche” (1816) teiste uute sõnade seas ära ka könnekänud. Masing kasutab seda publikatsiooni saksakeelsele sissejuhatusele järgnevas eestikeelses pöördumises, milles arutleb kohati üpris kriitiliselt võõrsõnade ja võõrväljendite emakeelde tungimise üle:

[---] Assusid sest ajast mitmed könnekänud, ja asjata ülleswoetud Kreka ja Prantskele sannad meie ramatutesse, ning perrisid maad meie suus [---] (Masing 1816a: 17).

Teksti sees sõrendatuna esitatud kõnekäänu olemust ta pikemalt sealjuures lahti ei seleta ning esitab selle uuesti põhitekstile järgnevas sõnaseletuste 
Foto 1. Lehekülg O. W. Masingu raamatust "Ehstnische Originalblätter für Deutsche”.

nimistus koos saksakeelse vastega Wendungen der Sprache nendele, "kellele mõndagi võib ehk tunduda tundmatu, kahtlane või meelevaldne" [siinkirjutaja tõlge]. Sealsamas esitab ta ka sõna laulo käänud, millele järgneb erinevalt esimesena nimetatust ka saksakeelne selgitus.

Ka sama 1816. aastaga dateeritavas kirjavahetuses Johann Heinrich Rosenplänteriga kasutab Masing oma erandlikult eesti keeles kirja pandud kirjaridades uut terminit - seostades seda hoopis saksakeelse terminiga Phra$s e$ - rõhutades taas kord eesti keele kasutamise tähtsust maarahvale mõeldud kirjasõnas:

[---] Et nü̈̈d neist ennestest kegi head enneselle ej woi sada, siis ommetige nemad sest polest woiwad kassuks tulla, mis üks ehk teine tark ja kelemoistja mees neie pärast teiste öppetusseks wöttab üttelda, ja ühhe ehk teise sanna ja könnekäno (Phrase) jurde seletuseks ehk paranduseks lisada. [---] (Masing 1816b: 144).

\section{i7}

Şrof̧wesferifs olfi, ja omma. Diftitonàriga ni fuurt fólla ja tülli ilmasfe ofli látfitanù.

aleg mis feif asjac úmbertoob, woitis fiis wimaf's faffafele waljust jo waefust, nenba et temma feige Eidrgema ja úllema laulo: laulja fui tönnepiobaja fuust lobbufoste fraffos fôllama, feige fönne ia firjutusfele cttelóma, ja funningategi todondes armfats fama. Gefis temma fiis ommas uefundinuo máes, iflus ja rammus is60 funni 1790 . Eest ajast baffas paljo mesfirousfufio, Euiwrago, fásno ja paf̧fafid ajama. Tienda fuida neil pámi! ilmas feif asjad feggafets ollio minnemas, nenis fiis fa faffafeel monne innimeste. julgusfe lábbi, fes wo.must ennefe pole fanub, bqafflas fero minnema. Xsfunto jest ajast mit: meo fónnetánao, ja asjata úlleswoetuo Rrefe ja Prantsfele fannad meie ramatufeş ning pertifio maad meic fuus. Wottis full man= na au wåtr Rampe feif ommab jo fuffnnuo ja mannafs lånub foaristad fătte, mis oflio: oleàrra mallitfema; fui monne teibis teistjuggu ebe fetffi ollewab, feoda diraheitma, omma ficeetnis asfemele panneme, ja nteib wib̧ma fiest $\mathbf{r}$ ådsta affa wima. Dtertio fainte fits pog. wa ja rendez-V ous asfemele: Sotterbet nuustif, fima ja lę̧helisfe puittifenne, ja bৃaffas meie feelt fưrima; temma fannafesfeo fui ernib 
Seegi lõik kinnitab, et just Masing oli see isik, kes esimesena kasutas eesti keeles terminit kõnekäänd. Paraku, nagu märgitud, ei selgitanud ta uut terminit lahti, mistõttu pole imekspandav, et sõna kasutus piirduski tollal üksnes Masinguga, laiemalt levimata. Näitena võib tuua perioodi olulisimaks eesti keele arendamisega tegelevaks väljaandeks peetava "Beiträge zur genauern Kenntniss der ehstnischen Sprache" (1813-1832), milles publitseeriti Rosenplänteri eestvõttel muu hulgas ka vanasõnu ja muid ütlusi, kuid nende nimetamiseks kasutati taas üksnes saksakeelseid termineid.

\section{Ütlusfolkloori-alasest terminoloogiast 19. sajandi teise poole publikatsioonides ja käsikirjades}

Eesti rahvaluule lühivormide olulise allikana 19. sajandi teisest poolest on eraldi esiletõstmist väärt Friedrich Reinhold Kreutzwaldi käsikirjaline vanasõnade ja kõnekäändude kogu (koostatud 1860. aastate alguses, lõpetatud 1864), mis koosneb 1038 üksusest, olles üks mahukamaid omasuguseid. ${ }^{12}$ Paraku puudub sellel kogul sisule viitav nimi ning seda põhjusel, et autor jättis käsikirja pealkirjastamata. Kirjavahetuses kaasaaegsetega räägib ta sellest kui vanasõnade kogust (näiteks kirjas Schultz-Bertramile 10. mail 1864 (Kreutzwald 1959: 173). Kreutzwald toetus suuresti Hupeli grammatikas toodule, aga lisas ka enda kogutut (ja ka endaloodut) ja lähematelt kaastöölistelt saadut. Kreutzwaldi käsikirjaline materjal leidis tee järgmistesse käsikirjadesse ja trükistesse, mis omakorda said aga allikateks järgnevatele trükistele (Krikmann 2006). Kõige eredamalt Victor Julius Steini käsikirjalises materjalis, mis ilmus trükituna pealkirja "Üks kubu Wanu-sõnu ja wanu kõnekombeid” all (1875) ning oli üldse esimene eestikeelne vanasõnaväljaanne. Samas sisaldab see ka tekste, mida Stein märgib pealkirjas terminiga kõnekombed ja eessõnas laiendatult "vanad kõnekombed ehk viisid", eristades neid sel moel vanasõnadest. Raamatus sisalduvale materjalile seda eristust autor siiski ei rakenda.

Kuigi võiks eeldada, et Kreutzwald täheldas erinevusi rahvapäraste ütluste puhul, ei saa näiteks ka tema kirjavahetusest oma kaasaegsetega - mis aitab käsikirjas selgust saada - välja lugeda kõnekäänu kui termini eestikeelset kasutamist. Põhjus peitub taas kord keelekasutuses, kuna tollased haritlased suhtlesid omavahel saksa keeles. Ütlusfolkloori märkimiseks kasutas Kreutzwald peaasjalikult saksakeelset Sprichwort ning näib, et ta koguni vältis vahetegemist, nimetades vanasõnadena ka ütlusi, mida tollases saksakeelses kirjanduses tavatseti tähistada pigem terminiga die sprichwörtliche Redensarten (Kreutzwald 1956: 349). Võib üksnes oletada, et ehk oligi just seesuguses vanasõnale osutavas seoses peidus põhjus, miks Kreutzwald eelistas kõnelda 
rahvakeelsetest ütlustest kui vanasõnadest või kui vanasõnadele väga lähedastest keelenditest.

Kreutzwaldi kirjavahetuses kohtab ka iseseisvat terminit Redensart, ent vaid mõnel korral. Ühel juhul näiteks pseudorahvaliku kõnepruugi tähenduses, kirjas Anton Schiefnerile aastast 1862 (Kreutzwald 1953: 287). Samas kirjavahetuses mõned aastad hiljem (1865) mainib Kreutzwald eesti keelele omaseid väljendeid rääkides mütoloogiast ja eufemistlikest nimetustest:

[---] Siin saate hamba proovimiseks midagi mütoloogilist. Kas lumetuisul on isiklik tekitaja? Eesti kõnekäänud: Tuisu eit, ka Tuisu Kadri (või Triinu) on möllamas, näikse selle poolt kõnelevat; iseäranis iseloomustav on kuud ümbritseva pärja järeltulev nimetus: Kuul on tuisueide kübar peas. Kas leidub midagi sellesarnast teistelgi rahvastel? [---] (Kreutzwald 1953: 333-334). ${ }^{13}$

Nagu näha, kasutab Kreutzwald terminit adjektiiviga eesti, pidades seega selliseid ütlusi ühele keelele eripäraseks.

Ka teise olulise tolleaegse kirjamehe Friedrich Robert Faehlmanni kirjades Kreutzwaldile kohtab üksnes terminit Redensart. Näiteks 4. veebruaril 1843. aastal, mil kirjamehed arutlevad võimaliku eesti-saksa sõnaraamatu struktuuri ja koosseisu üle (Faehlmann 1843). ${ }^{14}$ Samal teemal on vahetatud kirju veel mõned kuud hiljemgi samal aastal, seejuures on Faehlmann teinud seda koguni eesti keeles:

[---] Kas oled ju inimese kehajagude nimesid hakanud üle kirjutama? Pane veel mõne jao juurde kõneviisid (fraasikesed); võta ka meeste- ja naisterahva riided ette, vana isa Aadama viisi, kui ta elajatele ja rohtudele ja puudele igaühele oma nime andis [---] (Kreutzwald 1976: 64).

Faehlmann ei kasuta siiski eesti keeles mitte kõnekäänu-terminit, vaid räägib kõneviisidest, mida täpsustades nimetab saksa keele toetudes fraasikesteks. Deminutiivse vormi kasutamine on seletatav tõenäoliselt sooviga teha sel moel vahet pikemate üksuste ja nappide ümberütlevate nimetuste vahel. Seda, et Faehlmann tõepoolest pidas silmas kujundlikke keeleüksusi, annab tunnistust selgitus eelmainitud varasemas saksakeelses kirjas, kus toob näidetena sellised ühendid nagu peatükk ja läti kops (Kreutzwald 1976: 57).

Varasematele eesti keele leksikograafilistele allikatele omast vanasõnakeskset lähenemist kohtab ka eesti keele ja rahvaluule ühes olulisemas varasemas teaduslikus allikapublikatsioonis, Ferdinand Johann Wiedemanni teoses "Aus dem inneren und Äusseren Leben der Ehsten" (1876). Selles sisaldub rohkelt ütlusfolkloori, mis on rühmitatud saksakeelsetesse peatükkidesse: "Sprichwörter und sprichwörtliche Redensarten, Sentenzen, geflügelte Worte", 
"Umschreibende, bildliche und verblümte Bezeichnungen und Redensarten", "Sprichwörtliche Vergleichungen" (tõlkes 'Vanasõnad ja vanasõnalised ütlused, sententsid, lendsõnad', 'Ümberütlevad, piltlikud ja mõistu öeldud nimetused ja kõnekäänud', 'Vanasõnalised võrdlused'). Eestikeelseid termineid me sellest väljaandest ei leia. Küll aga sisalduvad ütlusfolkloori märkivad erisugused oskussõnad Wiedemanni seitse aastat varem ilmunud publikatsioonis "Eestisaksa sõnaraamat / Estnisch-Deutsch Wörterbuch" (1869). Tähelepanuväärne on terminite juures arvukate sünonüümsete oskussõnade esitamine, näiteks vanasõna kõrval toob ta veel wanaks jäänud sõna, wana-rahwa-sõna. Seejuures esitab Wiedemann sealkohal saksakeelse vastena tavapärase Sprichwort kõrval hoopiski Bauernregel (tõlkes 'talupoja elutarkus, -juhis') (1869: 1186), mida tollases saksa keeles tavatseti kasutada märkimaks mitte niivõrd vanasõnu, kuivõrd erilaadseid rahvapäraseid ütlusi ${ }^{15}$. Saksakeelset Sprichwort kohtab väljaandes muudegi sõnade vastena, näiteks liitsõna mõistusõna juures: Räthsel, Gleichniss, bildlicher Ausdruck, Sprichwort ('mõistatus, tähendamissõna, piltlik ütlus, vanasõna'). Eestikeelne termin kõnekäänd esineb märksõna kään all: kõnekäänid 'Wendungen, Ausdrücke in der Rede' (tõlkes 'väljendid, kõnes esinevad väljaütlemised') (1869: 282). Sealsamas leidub ka märksõna käänd, mille juures Wiedemann aga kõnekäändu ei maini. Saksakeelsete vastetena esitab ta sel kohal Redewendung, Redesatz (1869: 283), mitte aga tavapärase die Redensart, mida küll kasutab tosinal korral kogu sõnaraamatus märkimaks püsiühendeid. Kahe märksõna ühisosaks on saksakeelne die Wendung sarnaselt Masingule. Huvitaval kombel toob Wiedemann (1869: 943) ka märksõna pööre all liitsõna kõne-pööre, küll märkimaks lauseperioodi kõnes.

Wiedemannil leidub ka saksa Phrase ning seda vastena eestikeelsele sõnale kõne jätk (1869: 150). Saksakeelse Idiotismen vastena esineb Wiedemannil aga huvitav liitsõnaline moodustis, mida ei kohta üheski varasemas allikas: priisõnad (1869: 1186). Seejuures toob ta tähenduse laiendusena veel saksakeelse ungewöhnliche Wörter und Ausdrücke (tõlkes 'ebaharilikud sõnad ja väljendid').

Wiedemanni publikatsioonidele eelnesid keeleuurimisreisid Eesti- ja Liivimaale, mille kohta andis ta aru Venemaa Teaduste Akadeemiale kui rahastajale. 1861. aastal ilmunud esimesest aruandest leiab lõigu, milles ta kirjeldab oma kohtumist Kreutzwaldiga, toonitades viimase olulist abi sõnaraamatu koostamisel ${ }^{16}$ :

[---] Pikema suhtlemise tagajärjel, kus harva millestki muust kui eesti keelest juttu oli, tuli lõpuks kõne alla hulk sõnu ja omapäraseid kõnekäände, mida ma muidu võib-olla üldse poleks saanud, sest nad on enamuses niisugused, et võ̃oras vaevalt selle peale tulekski neid eestlase käest küsitlema hakata. Nende hulka kuuluvad nimelt ümberütlused ja piltlikud väljendused, millest eesti keel on nii rikas ja mis sagedasti 
on nii iseloomulikud rahva karakterile ja mõtteviisile. [---] (Kreutzwald 1953: 211-212).

Kuigi taas kohtab üksnes saksakeelseid termineid -Ausdrücke, Wendungen-, on kirjeldus tähelepanuväärne, kuna sisaldab esmakordselt eesti keele uurija sõnastatuna rahvalike ütluste lähemat iseloomustust, milles ühtlasi tuuakse esile ka nende suur osatähtsus ühes keeles.

Arvo Krikmann on oma "Lühivormide allikaloos" (1986) 19. sajandi teise poole väljaannetest Wiedemanni "Aus dem innerem..." ja Steini "Üks kubu..." kõrval toonud välja ka Carl Körberi "Wanna rahwa moistusse könned ja targad sannad” (1869). Raamat on tähelepanuväärne rahvaluule allikas, kuna sisaldab rikkalikult erisugust folkloori: loomajutte ehk valme, vanasõnu, mõistatusi ja ütlusi. Lühivormide hulk küündib koguni 400 tekstini. Enamik toodud tekstidest on kas vanasõnad, mõtteterad vmt, kõnekäänu-järku tekste on nende seas vähevõitu. Raamatus esitatud ütlusfolkloori nimetusega wannad sannad või targad sannad liigitab Körber keelte kaupa, milleks on maakeel, ladina, vene, prantsuse keel. Lisaks esinevad tal rubriigid piiblivanasõnadest ja vanarahva mõistusõnadest. Viimastele eelneb Körberilt ka selgitus, milles ta osutab Martin Lutherile, kes olevat kutsunud üles koguma rahvakeeles ringlevaid seda sorti ütlemisi (Körber 1869: 53). Krikmann on tuvastanud, et Körber kasutas oma raamatu allikmaterjalina nn Helle-Hupeli seeriat, aga tõenäoliselt ka mingeid muid allikaid (Krikmann 1999). Iseäranis nn mõistusõnade seas leidub tekste, mille päritolu on Krikmanni sõnutsi kõige hämaram (tekstid numbriga 41-50, lk 56).

19. sajandi lõpu keele- ja rahvaluuleväljaannetest on üks olulisemaid Wiedemanni eesti-saksa sõnaraamatu teine trükk (1893). Selle toimetamine usaldati Jakob Hurdale. On väga hästi teada, et koostöö oli vastastikune, kuna Wiedemann kasutas oma publikatsioonides rahvaluule ja rahvaliku kõnepruugi näidetena Kreutzwaldilt saadu (sh vanasõnade kogu) kõrval suuresti ka Hurda enda kogutud keelematerjali (Ariste 1971: 46). Ühtlasi täiendas ta olemasolevat sõnavara omalt poolt ligi 10000 uue sõnaga, mille Wiedemann oli kogunud pärast raamatu esitrüki ilmumist. Ka märksõna käänd all toodud kõnekäänd juurest leiab lisaks esiväljaandes toodule veel kaks saksakeelset vastet: $R e$ deweise, Wortform (Wiedemann 1973: 256). Samuti on Hurt märksa rohkem vasteid lisanud märksõnale ütlus, tuues nendena Sage, Ausspruch, Ausdruck, Redeweise, ning osutades seejuures ka selle sõna varasemale ja Hurda meelest vananenud tähendusele, milleks on 'jutlus' (ibid.: 1277). Mõlemast väljaandest leiab huvipakkuva fraasi wanad rääkimised, mille saksakeelse vastena esineb Traditionen. Ent erinevalt algväljaandest esineb Hurda toimetatud publikatsioonis sealsamas märksõna rääkima all veel fraas olgu rääkida, mille saksakeelse vastena toob ta das sind nur leere Redensarten (ibid.: 943). 
Eesti rahvaluule suurkogumiste korraldaja, rahvaluule- ja keeleuurija Hurda põhihuviks olid kindlad pärimuseliigid, mida ta tavatses nimetada vanaks varanduseks ehk vanavaraks. Nii kutsubki ta oma olulisimates rahvaluule kogumise üleskutsetes eesti muinasaja tundmiseks 1888. aastal ajalehe Olevik eri numbrites rahvast üles kirja panema rahvalaule, jutte, kombeid, aga samuti eesti rahva vanasõnu "ehk tarkuse terasid" ja mõistatusi. Selles nimistus ei sisaldu aga kõnekäände (Hurt 1888: 1). Ometi oli Hurt Eesti Kirjameeste Seltsi esimehena avaldanud seitseteist aastat varem Eesti Postimehe lisalehe vahendusel üleskutse "Mis lugu rahva mälestustest pidada", milles kutsub ennemuistsete juttude, rahvalaulude, mõistatuste ja vanasõnade kõrval paberile panema ka "tähtsad kõnekäänud ja mõnesugused arvamised, kas loodud asjadest või muust, mis inimese südant liigutab ja teda mõtlema paneb" (Hurt 1871b: 153). Kuigi ütlusfolkloori laekus kogumistöö tulemusena järgnevatel aastatel rikkalikult, ei eritletud neid siiski vanasõnadest ning see teeb nende üksuste arvulise väljatoomise keerukaks. ${ }^{17}$ Seda, et Hurt siiski oli tõepoolest väga hästi teadlik kõnekäänu olemusest, kinnitab ka esimese üleskutsega samal 1871. aastal ilmunud kirjutis "Kas eestikeelele uusi sõno tarvis", milles ta mitmes lõigus toonitab kujundlike kõnekäändude olulisust keeles.

[---] Ka meie mõtetel on omad riided ja meie kõnel omad riistad ja need on keele mitmesugused sõnad ja keele mitmesugused käänud. Mida sündsam mõttel riie, seda nägusam ja selgem on mõte; mida rohkem kõnel riisto, seda enam tööd wõib kõne teha; mida täielikumad need riistad, seda täielisem saab ka töö olema. [---] (Hurt 1871a: 130.)

Seejuures märgib Hurt väga õigesti, et sarnaselt sõnadega võivad kujundlikud ütlusedki keelde sugeneda teiste keelte vahendusel:

[---] Tuleb uus sõna ehk kõnekäänd lugedes ette, siis ei tohi meie enam nuriseda ja uriseda, et ta ette tuleb, vaid peame temalt üksi passi nõudma, kas tal õigus ette tulla ja Eestikeeles kodaniku passi nõuda. [---] (Hurt 1871a: 130). ${ }^{18}$

Siiski ei maini Hurt vaid mõned aastad pärast esimest üleskutset, 1875. aastal välja käidud rahvaluule publitseerimise kavas enam kõnekäände, vaid kõneleb üldistatult "vanast tarkusest ehk vanadest-mõistusõnadest" (Hurt 1875: 101). Oma hilisemates pöördumistes loobuski Hurt vähehaaval erinevate rahvaluuležanride alaliikide täpsemast eristamisest. Seda, miks otsustas keelemees, vaatamata seesuguste keelendite olulisuse tajumisele, nad ikkagi kõrvale jätta, on tagantjärele keeruline tuvastada.

Oli selleks siis Hurda mõju või muud põhjused, aga üha tugevamalt koondus rahvaluulekogumise põhitähelepanu regilauludele ja muu rahvaloome jäi 
selle kõrval varju. Teisedki Eesti Kirjameeste Seltsiga seotud rahvaluuletöö eestvedajad jätkasid sama liini, nimetades oma üleskutsetes rahvaluule kogumiseks laulude ja juttude kõrval küll lühivorme, aga ka siis üksnes vanasõnu ja mõistatusi, mitte rahvapäraseid ütlusi. Näitena võib tuua Jaan Jõgeveri 1886. aastal ajakirjas Oma Maa, Juhan Kunderi 1886. aastal ajakirjas Meelejahutaja ${ }^{19}$, Matthias Johann Eiseni 1887. aastal ajalehtedes Olevik ja Postimees. Siiski leidus seltsi liikmete seas huvilisi, kes avaldasid rahvaluulekäsitlusi rõhuasetusega just lühivormidel. Nii esitab esmakordse teoreetilise kirjelduse eesti vanasõnadest kooliõpetajast rahvaluuleentusiast Joosep Kapp oma artiklis "Vana-sõna" (1873), tuues eraldi välja ka kõnekäänud:

Ütleb aga rahvas ühte paljast asja, ilma täieliku mõtteta, ehk ühte poolikut mõtet välja, siis ei ole see mitte vanasõna, vaid meie võime niisugusid rahva avaldamisi vana-sõnaliseks kõnekäänuks nimetada, nagu "Enneaegne vader”, "Kül ilm õppab”, “Anna aega adra seada!”, "Kuri karjas” jne (Kapp 1873: 38).

Nagu näha, mõistab sarnaselt varasemate keele- ja rahvaluuleuurijatega ka Kapp kõnekäändu mitte omaette žanrina, vaid millenagi, mis on genuiinselt seotud vanasõnaga.

Kooliõpikutest on 19. sajandi teisest perioodist silmapaistvaim Carl Robert Jakobsoni "Kooli lugemise raamatu" sari (I 1867, II 1875, III 1876). Nendes esitatud lugemispalade järel esineb ka vanasõnu. Lisaks kohtab ka paari eraldi jaotist vanasõnade ja mõistatuste, aga mitte kõnekäändude kohta.

Kui uurida teisi tollaseid õpikuid ja sõnaraamatuid, siis Eesti Kirjameeste Seltsi 1876. aastal kirjastatud "Vene keele õppimise raamat eesti rahvakoolidele”, autoriks Carl Heinrich Niggol, sisaldab küll ohtralt vanasõnu, ent enamik neist kujutavad endast tõlkeid-mugandusi vene keelest. Raamatu lõpus on ka omaette peatükk "Lugemise tükid, laulud, kõnelemised", milles leiduv loend on pealkirjastatud "Пословицы” / "Wanad mõistu sõnad”. Seega sarnaselt Hurda poolt sõnastatule. Alates viiendast trükist (1887) leiab juba iga grammatikapunkti lõpust vanasõna, kuid mitte eesti, vaid vene oma.

Sama seltsi poolt 1885. aastal välja antud ning hiljem korduvalt uuesti välja antud Jakob Johanson-Pärna toimetatud "Vene-eesti sõnaraamatust" leiab sõnad фбраза 'lause, ütelus' ja поговорка, mille vastena on toodud aga 'wanasõna'. Kuna viimane (mingil põhjusel sel korral küll lahku kirjutatuna) esineb ootuspärasena venekeelse märksõna пословица juures, saab taas nentida, et 19. sajandi lõpuni valitses ütluste eristamise vallas suur terminoloogiline segadus.

Karl August Hermanni “Täielises Eesti-Wene sõnaraamatus” (1889) sisaldub kõnekäänd sõnasõnalise venekeelse vastega обороть ръчи. Sellest aga, et Hermann mõistab kõnekäände mõneti mitte niivõrd rahvapäraste väljendite, 
vaid pigem poeetiliste sõnaühenditena, annab tunnistust üks lõik peatükist "Hääleõpetus" tema "Eesti keele grammatikas" (1884):

[---] Salmikute keele ilu pärast hoiawad endid peenikese tundmusega luuletajad ka selle eest, et mitte järgmine sõna selle häälikuga ei alga, millega eel minew on lõpnud, näit.: aja arw, ole ees, hoop pea, suur rida ie., vaid nad püüawad ikka teha, et järgmine sõna teise häälikuga pääle hakkab, sest et siis keelel ilusam kõla on. Siin ei wõi aga iga kord nii waljult seadust pidada, muidu ei wõiks mõndagi ilusat kõnekäändu tarwitada, näit.: Eesti isamaa, isamaa-armastus. [---] (Hermann 1884: 17).

Samal 1884. aastal ilmus ka Jaan Nebocati"20 "Kündja. Eesti keeleõpetus nenda kui Eestikeelt Kesk-Eestimaal räägitakse", milles autor toetub Eduard Ahrensi ja Wiedemanni põhimõtetele.

Peatükis "Esimene nimisõna muutmine" kohtab määratlust mõistusõnalised kõnekäänud ja nende näidetena peaasjalikult rahvakeelseid liitsõnalisi nimetusi:

[---] Sõnad ühe ainsa pitka liikmega. Ärakadunud healega tähte, kelle kadumise läbi need sõnad üheliikmeliseks on saanud, peab sõnaraamatust otsitama. Üksnes mõne kokkupandud sõna ja mõistusönaliste kõnekäänide sees on neid weel näha, nagu haganik leiwa jätku, humalik olle jätku, wesi pitka piima jätku, raagapurje, jõhwihein, wette lasku aeg, karjalaskupäew, örkuroog, tuhkapunn, tuhkapäew, tuhkapass, tuhkapemp, pelgupaik, wihku silmaga, waikupuu, wänta-köis, teistest muutmistest weel hiiri täht, tuuliweski, ei üksigi (= ̈̈kski). [---] (Nebocat 1884: 44).

Nebocati toimetatud saksa-läti-vene-eesti sõnaraamatus (1885) leidub ka eraldi peatükk pealkirjaga "Kõnewiisid” (paralleelnimetustena vene Выражения, saksa Redensarten), mis sisaldab peaasjalikult näiteid kõneviisi kui morfoloogilise kategooria kohta. Siiski kohtab näitetekstide seas ka mõningaid argivormeleid, näiteks: Kuidas käsi käib? - Ikka käisest läbi. Tuhat tänu! Jätka jumal leiba!.

Võib väita, et nii Hermann kui ka Nebocat olid teadlikud kõnekäänu olemusest, mõistes neid kui grammatilisi sõnakombinatsioone, mis ei ole keeles tavapärased ehk on reeglitest hälbivad.

Nebocati koostatud eesti-saksa sõnaraamatus (põhineb Ahrensi, Wiedemanni ja Puttkameri reeglitel) esineb kõnekäänd, ent mitte omaette märksõnana, vaid sarnaselt varasematele väljaannetele märksõna käänd all. Seejuures tuuakse saksa vastetena sarnaselt Wiedemanni sõnaraamatule Redewendung, Redesatz (Nebocat 1889: 188). Vanasõna eestikeelsete terminitena tuuakse välja veel wanarahwasõna 'Sprichwort, Bauernregel' ja mõistusõna 'Sprichwort, Sentenz, Gleichnis, Rätsel, bildlicher Ausdruck' (ibid.: 502). Ka nende sõnade saksakeelsed vasted pärinevad Wiedemanni teose esitrükist. Sellest annab 
tunnistust ka eestikeelne nimisõna ütlus, mille puhul esitab Nebocat samuti üksnes napi osutuse märksõnale jutlus. Saksakeelne Redensart (kõrvuti terminiga Ausdruckweise) esineb nii Wiedemannil kui ka Nebocatil vastena liitsõnale kõnemood ja märksõna rääkima tähendusseletuste hulgas ühe fraasi koosseisus (olgu rääkida - das sind nur leere Redensarten).

Eesti Kirjameeste Seltsi poolt publitseeritud "Eesti-Wene sõnaraamatus" (1890, autor Marcus Salem, kelle koostatud käsikirjaga jätkas Juhan Kunder, ning kelle töö omakorda viis lõpule Timotheos Kuusik) on samuti kõnekäänd leidnud koha ning sarnaselt Hermanni samalaadsele sõnaraamatule venekeelse vastega обороть ръчи. Eestikeelse omatermini esinemisele on hõlbus seletus, kuna ka selle sõnaraamatu märksõnad ja näitestik pärinevad Wiedemanni sõnaraamatust.

\section{Ado Grenzstein ja "kahtlane uus sõna"}

19. sajandi lõpul välja antud teedrajavaima sõnastiku autor on Ado Grenzstein väljaandega "Eesti sõnaraamat" alapealkirjaga "1600 uut ja wõerast sõna korjanud ja (Saksa sõna lisandusega) Eesti keeles selgitanud A. Grenzstein" (1884). Autori toodud sõnade seast leidub ka kõnekäänd. Selle vastena toob ta saksa termini die Phrase ning annab selgitusena 'ütlemise viis, kõnelemise pruuk, mingi isesugune lause' (Grenzstein 1884: 68). Samas arvab ta kõnekäänu aga kategooriasse "Kahtlased uued sõnad" (muud kategooriad: "Soovitavad uued sõnad", "Wõerad ja halwad uued sõnad"), pidades seega seda keelendit pigem ebasobivaks. Kuna on kindlaks tehtud, et suur osa Grenzsteini sõnadest pärinevad Wiedemanni sõnaraamatust (Raag 2008: 106), võib oletada, et ka kõnekäänd on raamatusse sisse võetud just sel põhjusel. Kuigi on üldteada, et Grenzsteini kui keelelise purismi eestvõitleja eesmärk oli vältida keeles eelkõige uusi laen- ja võõrsõnu, jääb siiski arusaamatuks kõnekäänu arvamine selliste sõnade hulka. Iseäranis, kui võtta arvesse selle ligi 70 aasta tagust esmamainimist Masingu publikatsioonis. Näiteks järjekindlusetusest võib tuua, et kuigi Grenzstein pidas saksa keele mõjulist kõnekäänu-terminit pigem sobimatuks, seostas ta seda omadussõnaga eestiline ehk rahvusele omasena: Eestlaste viisi järeline, Eestlaste omaline, Eestimaal pruugitaw, Eesti loomu järeline; eestiline kõnekäänd, eestiline pruuk (Grenzstein 1884: 24).

Grenzsteini veendumusest sellise termini ebasobivuse osas annab tunnistust ka "Eesti Lugemise-Raamatu" sari (1887-88), milles leiduvad rubriigid nimetustega "Vanad-sõnad", "Mõistatused" ning “Mõttesalmid”, aga mitte kõnekäände sisaldavat peatükki. Grenzstein koostas ka vene keele õpiku, mille ta pealkirjastas "Riigikeele Õpiraamat Eestlastele" (1890). Selles toob ta iga 
lugemispala või laulu järel vanasõna või mõistatuse, aga ka näiteks kiirkõnena määratletavad tekstid (mida ta märgib kohmaka moodustisega sõna ruttuütlemiseks $)^{21}$. Neid rahvaliku elava kõne näiteid tähistavad terminid esitab autor ka raamatu lõpus olevas sõnastikus. Kõnekäändu me seal toodud sõnade seast ei leia.

1899. aastal ilmunud brošüüris "Kauni keele kaitsemiseks" kasutab Grenzstein terminit sõnakõlks. Selle toob ta vastena saksa sõnale Phrase, selgitades seejuures tähendust aga kõnekäänu-termini abil:

Sõnakõlks, phrase. Kreeka sõna phrase <frase> tähendab kõnekäändu, millel nagu wanasõnal oma kindel kuju on, milles ta ikka ette astub. Ajajooksul jääb phrase aga enam wähem tühjaks kõnekõlksuks, millel sisu sees ei ole (Grenzstein 1899: 11).

Sellest määratlusest tuleb selgelt ilmsiks, et kuigi Grenzstein kõrvutas kõnekäändu vanasõnaga, siis tegi ta seda üksnes vormi poolest, pidades seda millekski, mis muutub ajapikku sisutühjaks väljenduseks. Grenzsteini programmilisest sõnavõtust võib mitmel leheküljel kohata suisa põlgust seesuguse keelenähtuse suhtes. Iseäranis näib talle olevat vastumeelt nn rahvaliku keelekasutuse järeleaimamine, sh piltlike kõnekäändude kasutamine nii ajakirjanduses kui ka kujunevas eestikeelses ilukirjanduses.

[---] Sügaw mõte, kirjaniku kaunim ehe, peidab end sagedaste kõnekäänu taha ära, kust ta aga leidmise juures seda suuremat lõbu saadab. Tabab kirjanik, kellel kord aluspõhja ader käepärast ei ole, siisgi sügawaid asju awaldada ja seda sasise, uduse keele abil teha, et lugejas mõtet äratada, nagu ei ulataks tema mõistus udupilwe saladusi nägema, siis ole julge, et sa waremine ehk hiljemine petjana oma lugeja silmade ees seisad. [---] (ibid.: 32).

Selles Grenzsteini halvustavas suhtumises võib näha lähtumist tollastest saksakeelsetest sõnaraamatutest, kus 19. sajandi teiseks pooleks oli termini Phrase algne tähendus muutunud negatiivseks.

Kui heita pilk muudele tollastele väljaannetele sõnaraamatute ja õpikute kõrval, siis näiteks "Eesti kirjanduse ajaloo" rahvaluulele pühendatud esimeses osas (1899) mainib Tõnu Sander ka kõnekäände, eritledes neid millenagi, mis paiknevad vanasõnade ja mõistatuste vahel. Ühtlasi iseloomustab ta seda tüüpi tekste ka veidi lähemalt:

Iseäralise vaheosa vanasõnade ja mõistatuste wahel sünnitavad nõndanimetatud kõnekäänud. Nende waral annab keel sõnades ilmuwale mõttele nägusama näo, kenama kuju; nende waral pü̈̈ab ta kõne sisu piltlikult kuuljale selgemaks teha (Sander 1899: 69). 


\section{Kõnekäänu-termini esinemine 20. sajandi algupoole väljaannetes}

Nagu eeltoodust näha, ei saanud kõnekäänust kinnistunud terminit veel 19. sajandi lõpuks. Võib ainult oletada, et ehk oli üheks põhjuseks kõnekäänu kahetine loomus - ühelt poolt iseseisev keeleilming, teisalt tugev seotus vanasõnaga - milles oma osa on ka saksa keele mõjudel.

20. sajandil alguses ilmunud publikatsioonides kohtab kõnekäänu-terminit siiski üha sagedamini. Nii on Timotheos Kuusiku koostatud sõnaraamatutes "Wene-Eesti ja Eesti-Wenekeelne sõnaraamat" ("Русско-эстонскій словарь и эстонско-русский словарь”, 1900) ја “Wene-Eesti ja Eesti-Wene sõnaraamat" (Русско-эстонский и эстонско-русский словарь, 1903) ${ }^{22}$ esitatud nii fraas kui ka kõnekäänd. Küll selle vahega, et esimene esineb üksnes vene-eesti pooles ning tähendusselgitusega 'lause, ütelus'. Termin kõnekäänd on toodud venekeelse поговорка vastena (kujul kõnekään), kuid mitte esimesena, vaid vanasõna järel teisena. Sõnastiku eesti-vene osas leiab selle aga märksõna kõne alt (kujul kõnekäänd) venekeelse vastega обороть рыци. Selline esitus sarnaneb Eesti Kirjameeste Seltsi 1890. aasta sõnaraamatus esitatule. See on seletatav asjaoluga, et Salemi töö viis lõpule just Kuusik. Kummastava seigana torkab aga silma, et vene-eesti pooles поговорка vastena toodud vanasõna puudub eesti-vene sõnastikus märksõnana sootuks.

Kooliõpikute puhul on märgatav rahvaluuletekstide osakaalu suurenemine. Seejuures toovad autorid välja ka rahvapärimuse rolli koolihariduses. Mihkel Kampmann nimetab oma "Kooli Lugemiseraamatus" (1905), mis mõeldud 1.-3. kooliastmele, kõnekäände kui keele rikastamise võimalust:

[---] Lugemiseraamat on alguskoolis emakeele õpetuse alus. Ta ülesanne on last kirjakeelega tutwustada, lapse enese keelt sõnade tagawara ja könekäänude poolest rikastada, õigeid wormisid tundma õpetada ja suusõnalikus ning kirjalikus mõtete awaldamises eeskuju pakkuda. Lugemiseraamat peab ukseks olema rahwa kirjandusesse. [---] (Kampmann 1905: III).

Samas näiteid kõnekäändudest õpikust ei leia, küll on kasutatud rohkelt vanasõnu, seda nii omaette alapeatükis "Eesti vanasõnad" (peatükis "Kõlbuline elu") kui lugemispalade lõpus. Kaks aastat hiljem ilmunud "Kooli Lugemiseraamatu" teises jaos (1907) leiab peatükist “Järelemõtlemiseks" alarühmad, mis sisaldavad mõistatusi, mõttesalme, vanasõnu ja ka kõnekäände (74 üksust). Viimaste olemust Kampmann ei määratle, küll aga toob ta raamatu lisas "Lühikene seletus kirjanduse toodete koorest ja sisust" ühe alapunktina "Kujurikas ehk piltlik sõnastus”, milles iseloomustab lähemalt troope, sh võrdlust, metafoori, 
allegooriat, omistades neid küll üksnes ilukirjandusele (Kampmann 1907: 324). Kõnekäändu mainib Kampmann punkti "Harutused” (kõrvutavalt proosa kirjatööde teiste liikidega nagu "Kirjeldused" ja "Jutustused") all: "Sissejuhatus peab lugeja otse thema juurde viima ja thema tõsise mõttesisu piltlikkudest kõnekäänudest jne. välja koorima ja selgeks tegema." (ibid.: 331). Seesugune seletus annab aimu arusaamast, mille kohaselt kõnekäänd kui kujundlik keelekasutus ei kuulu mitte igasugusesse kirjalikku tekstiloomesse.

Kampanni koostatud teosest "Eesti kirjanduseloo peajooned" (I 1912) leiab eesti rahvaluule käsitluse osas alapeatüki vanasõnadest ja mõistatustest. Viimane ei lisa aga midagi uut ja originaalset senistele arusaamadele. Nagu märgib ka Ingrid Sarv, on Kampmanni seisukohtades vähe iseseisvust, kuna ta toetub Kapi ja Sanderi käsitlustele (Sarv 1964: 113). Kõnekäände mõistab Kampmann üksnes vanasõnade ja mõistatuste vahepealsena:

Wahelüliks wanasõnade ja mõistatuste vahel on rahwa kõnekäänud. Nende varal annab rahvas awaldatawale mõttele kenama kuju, pü̈̈ab nende waral kõne sisu kuulajale piltlikult selgeks teha. Piltlik kõne, iseäranis wõrdlused, metaforid, liialdused jne., annawad sõnastusele elu, mõnu ja magu (Kampmann 1912: 132).

Seda, et Kampmann teeb selgelt vahet kirjanduslike ütluste ja rahvaluulesse kuuluvate ütluste vahel, osutavad nimetused rahwasõnad ja rahwa kõnekäänud. Kampmann rõhutab sarnaselt teistele uurijatele kõnekäändude erisugust kohta ja rolli, milleks on kõnele kujundlikkusse lisamine. Näitlikustamiseks toodud kümme teksti (teiste seas asjaks tegema, silmad hammaste vahele võtma, kulda ja kurja pakkuma, nüüd on oinad aia taga) sisalduvad juba sama kirjamehe "Kooli Lugemisraamatu" teises osas (1907). Kampmanni õpikudlugemikud osutusid väga populaarseteks, millest annavad tunnistust arvukad uustrükid järgneva 20 aasta jooksul.

Sama perioodi kooliõpikute teise viljaka autorina saab välja tuua Madis Nurmiku. Tema koostatud emakeelelugemikest leiab lugemispalade lõpust rohkelt ka vanasõnu ja mõistatusi. Kui esimeses väljaandes "Eesti Kooli Esimene lugemik" (1920) kõnekäände eraldi nimetatud ei ole ning vaid siin-seal tekstides kohtab püsiväljendeid, siis teises ja kolmandas täiendatud trükis on lisatud lühivormide näitetekstide loetelu ette vahepealkirju nagu "Kõnekäänud kirjast ja kirjaoskamisest”, "Hääst ja paremast. Kõnekäänud ja vanasõnad”, "Mõistu-kõnekäänud". Huviäratav on juba mainitud nimetus rahvasõnad. Nimelt kasutab Nurmik seda vanasõnade ja kõnekäändude vahele jäävate ütluste kohta, milleks on nn poeetilised ilmaended ning mis on seotud kalendripühadega. Õpiku kolmanda trüki pealkirjaga "Esimene lugemik" lõpus lisana toodud "Mõistatuste ja kõnekäändude võti" (Nurmik 1923: 344) sisaldab mõistatuste 
lahenduste kõrval kõnekäändude seletusi, iseäranis nn mõistu-kõnekäändude puhul, näiteks: vesi ahjus ja tuli ojas 'suur häda', hing niidiga kaelas 'surma häda', surm suu ääres ja kalm kaelal 'viimne häda', vene vile lööma 'nutma'. Nurmiku "Teise lugemiku" (1921) eessõnast aimub, et varasemate lugemikega võrreldes on rõhuasetus muutunud ja kirjandustekstide asemel kohtab rahvaluulet veelgi enam, mis aitab omandada paremini ka kirjakeelt, nagu autor toonitab. Seejuures toob Nurmik esile rahvaluule lühivormide kui rahvakeele parimate näidete osatähtsuse koolihariduses. Tähelepanuväärne on tema arusaam ütluste kuulumisest juba väikeste laste sõnavarasse (õpik on mõeldud 2.-4. õppeaastaks). Ühtlasi jagab Nurmik juhiseid rahvakeele sidumiseks kirjakeele ja kirjanduse õpetamisega, olles sel moel esimene eestikeelne metodoloogiline vahend kõnekäändude õppetöös kasutamiseks.

[---] Kõige huvitavam, aga ühtlasi ka metoodiliselt kõige raskemalt käsitatav element terves raamatus on kahtlemata rahvakeele ja -luule proosaained - kõnekäänud, vanasõnad, mõistatused. Neil on eesmärgiks õpetada elavat rahvakeelt ta tabavate ütluste ja särava naljaga. Et anda lapsele võimalust ka isetegevuseks, kes ses eas omab juba võrdlemisi suure hulga kõnekäändusid, siis on neist lihtsamad ja üldiselt tuttavamad meelega välja jäetud. Õpetaja kehutusel toovad siis õpilased suure rõõmuga oma teaduvara veel selle lisaks välja. [---] (Nurmik 1921: V).

Seoses rahvakeelele omistatava tähtsusega lisandus Nurmiku õpikutesse aina rohkem ütlusfolkloori. Sealjuures käis autor välja ka uusi nimetusi sedalaadi näitetekstide märkimiseks-liigitamiseks. Nii leidubki kõnekäände sellistes peatükkides nagu "Võrdlevad kõnekäänud", "Rahvakeele ütlused", "Naljakõnekäänud"23, "Keelenaljad", "Kuidas vahel öeldakse". Nagu neist kohati kattuvatest nimetustest nähtub, ei olnud ütlusfolkloori süstematiseeritult esitamine tõepoolest, nagu Nurmik ka ise eessõnas möönab, hõlbus ülesanne. Nii esineb tal kõnekäänuna määratletavaid tekste erinevate nimetuste all, sealjuures puudub neis läbivalt üks põhimõte: kord on eristuse aluseks vorm, kord sisu. Ka rühm pealkirjaga "Kõnekäänud ja vanasõnad" annab aimu liigitamisega seotud raskustest. Ilmaga seotud ütlused on esitatud erinevate alarühmadena nagu "Vanasõnad ilmadest" ${ }^{24}$ "Kõnekäänud ja vanasõnad ilmast". Varasemas väljaandes olid taolised ütlused koondatud üldnimetuse "Rahvasõnad" alla, mis nüüd sisaldab üksnes rahvalauludest pärit riimilisi ütlusi. Seejuures on aga kiiduväärt autori oskus osutada erinevate rahvaluuleilmingute omavahelistele seostele, jagades ühtlasi noore lugejaga etnograafilisi teadmisi.

Matthias Johann Eiseni "Meie wanahõbe" (1913) on pärast Steini raamatut esimene omataoline üksnes paröömilisele rahvaloomele pühendatud teos. Sellele osutab ka teose alapealkiri "Sarjatäis Eesti rahva endist tarkust, 


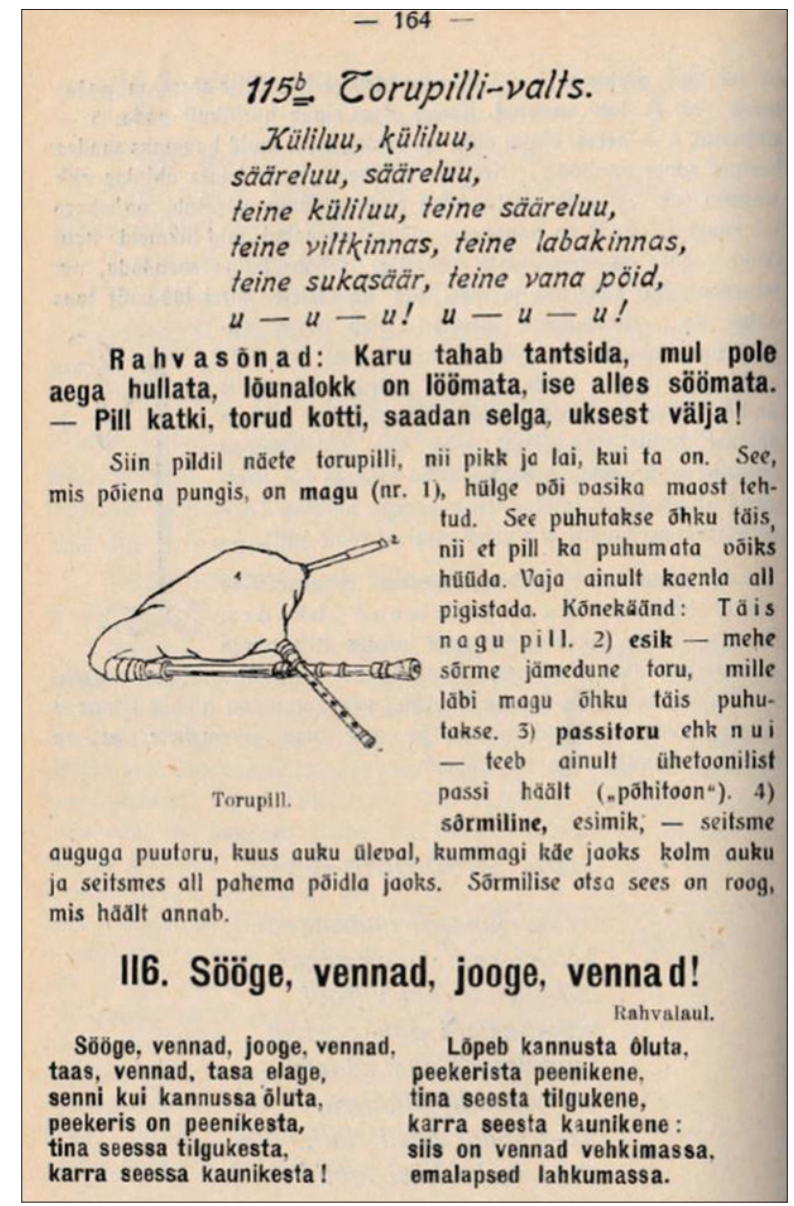

Foto 2. Lehekülg M. Nurmiku raamatust “Teine lugemik”.

kõnekäänusid ja ütlusi”. Ühtekokku sisaldab väljaanne ligi 1500 üksust, sh tuhatkond kõnekäändu. ${ }^{25}$ Krikmann on teinud kindlaks (1999), et suuresti sisaldab see Eiseni enda käsikirjalist materjali, milles aga ebaautentse ainese osakaal on suur. Seejuures on ka materjali paigutamine rubriikidesse ebaselge, näiteks sisaldavad kõnekäände nii "Võrdlevad kõnekäänud”, "Mõistatuslised kõnekäänud" kui "Üleüldised kõnekäänud ja ütluse viisid”. Eessõnas pealkirjaga "Sarjatäis wana tarkust" märgib Eisen:

[---] Aastasadade jooksul korjatud elutarkuse on meie esivanemad osalt lauludesse, enam aga mõttesalmidesse, wanusse sõnusse, kõnekäändudesse, mõistatustesse ja wanusse lendlausetesse pununud. Sarnaseid 
aineid leidub rahwasuus hulga kaupa. Rahwalaul lausud niisuguse tarkuse kohta: Mul on sõnu sadasid, Sadasida, tuhandida, Mitu suurta sarjatäita, Sarjatäita, sülletäita! Kõiki neid sadasi sületäisi korraga ette tuua, paneks ehk "wärisema, pelgama" nagu rahwalaul ütleb. Seepärast avaldame seekord ainult sarjatäie wanatarkust ebatarkuse kõrval, kui ka rahwa kõnekäänusid ja ütlusi. "Koju jätsin koti täie” ütleme rahwalauluga edasi. Wanasõna wanahõbe, ütleb rahwas ise ja niisama - wanalsõnal on kuldne sisu sees ehk kuldne põhi all. Ära wõta wihaks ega pane pahaks: wana kõnekäänd. Kõnekäänd kõnele, sool supile. [---] (Eisen 1913).

Vaatamata puudustele on ilmne, et Eisen tegi selget vahet vanasõnade ja kõnekäänuliste ütluste vahel, eristades viimaste puhul ka alaliike, mis on juba samm edasi võrreldes varasemate väljaannetega. Näiteks eelmainitud kaks rühma sisaldavad tekste, mis erinevad eelkõige vormiliselt - kui nn mõistatuslised kõnekäänud on fraasikujulised (nt hagu alla panema = enne pruukosti sööma), siis "Üleüldised kõnekäänud ja ütluse viisid" sisaldab lausekujulisi ütlusi (nt Ega rott või salwe surra. Ei sünni sööma ega mahu magama. Kes vaese häda usub!).

Paraku kõigest aasta hiljem ilmunud "Eesti vanadsõnad" (Eisen 1914) ei sisalda nii ühest lähenemist, nagu on kriitiliselt märkinud ka lühivormiuurija Ingrid Sarv (1964: 112).

\section{Fraseologismi-termini tulek eesti keelde}

Vaatamata materjali määratlemisega seotud raskustele, võib väita, et kõnekäänud olid leidnud vanasõnade ja mõistatuste kõrval lõpuks kindla koha 20. sajandi alguse kooliõpikutes, tekstikogumikes, kahekeelsetes sõnaraamatutes jm publikatsioonides. Samas puudus aga eesti keele kasutajal ikka veel suunava olemusega õigekeelsussõnaraamat, mis oleks aidanud terminoloogias selgust saada.

Kui 1918. aastal ilmus esimene eesti keele normeeriv sõnaraamat "Eesti keele õigekirjutuse-sõnaraamat", siis ei leia sellest ei kõnekäändu ega vanasõna, ning seda põhjusel, et liitsõnad on, mõne erandiga, välja jäetud. Küll aga sisaldub väljaandes sõna fraas. Kuna sõnaraamatu eesmärgiks olid õigekirjutuse ja sõnamuutmise reeglid, siis seda, mida selle sõnaga märgitakse, me teada ei saa. Seitse aastat hiljem ilmus märgatavalt täiendatud "Eesti õigekeelsuse-sõnaraamat" (1925), koostajateks Johann Voldemar Veski ja Elmar Muuk, mille esimeses köites (A-M) on lisaks juba varem esitatud fraasile ära toodud nii kõnekäänd kui ka kõnekõlks. Tähelepanuväärseim on aga fakt, et esmakordselt leiab eestikeelsest sõnaraamatust sõnad fraseoloogia ja 
fraseoloogiline. Terminid, mida saksa keeles võis kohata juba 17. sajandi algu$\operatorname{ses}^{26}$, tulid oma praeguses tähenduses - ühele keelele ainuomased püsivad sõnaühendid või fraasid - käibesse siiski alles 19. sajandi lõpul (Fleischer 1997: 3). Nende esmaseks ilmumiskohaks oli saksakeelne õppematerjal prantsuse keele omandamiseks "Deutsch-französische Phraseologie in systematischer Ordnung. Ein Übungsbuch für Jedermann, der sich im freien Gebrauch der französischen Sprache vervollkommnen will", autoriks Bernhard Schmitz (1872). Selles raamatus sisalduvate erinevate alapeatükkide pealkirjades kohtab termineid Redewendungen, Redensarten, Ausdrücke, Phrasen, aga ka Phraseologie. Autor selgitab viimast lähemalt eessõnas (Schmitz 1872: IV), tuues välja ka prantsuskeelse phraséologie, ning rõhutab asjaolu, et see mõiste on kahetähenduslik: ühelt poolt ühe keele kujundlike üksuste kogum, teisalt õpetus, mis hõlmab fraaside kasutamist ja tähendust. Arusaam, mis käibib tänaseni. Fraseoloogia teoreetilise külje arendamisse on olulisima panuse andnud lingvist, Genfi koolkonna esindaja Charles Bally, kes 1909. aastal tuli välja oma teoses "Traité de stylistique française" teooriaga, mis võeti aluseks eri keelte fraseoloogiauurimises, iseäranis esileküündivalt saksa ja vene keele puhul (Fleischer 1997: 4). Kuivõrd oldi aga Bally seisukohtadega kursis tollases Eestis, võib üksnes oletada. ${ }^{27}$

Eesti keele arendamise ajajärgul oli oma osa ka keeleuuendusel, mida kõige eredamalt esindas Johannes Aavik. Tema just varasemate tööde puhul on märgitud nendes valitsevat vastuseisu eesti keele saksapärasusele ja soovi avardada eesti keelt teiste kultuurkeelte toel (Ross 2005: 524). Võiks arvata, et Aavik, kes huvitus prantsuskeelsest keeleteadusest, oli teadlik Bally töödest. Antud artikli kontekstis on igal juhul tähelepanuväärne tema arusaam fraseoloogia olulisusest keele rikastamise vahendina. Oma programmilises raamatus "Keeleuuenduse äärmised võimalused" märgib Aavik:

[---] Ja üldse tuleks keele fraseoloogilise rikkuse eest hakata eritist hoolt kandma, sest rikas ja mitmekesine fraseoloogia on pääasjaliselt see, mis annab keelele ta kirjakeelse ja kultuurilise jume: mida arenenum too, seda peenem ja haritum see. Selle poolest näib saksa keel kõik muud keeled ületavat. Eesti keel aga on kirjakeelse, harit fraseoloogia suhtes alles õige kehv; sel puudub terve rida üsnagi tarvilisi vasteid saksa, vene, prantsuse, isegi soome omile. Samuti tahaks, et meie keeles ka palju omapäraseid fraseoloogilise ütlusi kujuneks. [---] (Aavik 1924: 99-100).

Lähemal vaatlusel ilmneb, et keelemees pidas eelkõige silmas kitsamalt idiomaatilisi verbiühendeid, kasutamata küll seesugust määratlust ennast. Ning kuigi Aavik käsitles fraseoloogiat eelkõige kui kirjakeele ilmingut, eristades seda rahvakeelsest kujundkeelest nagu kõnekäänud, hindas ta viimastki kõrgelt: 
Nii, oo tulevane eesti keel, harit ja peen, yhevõrdne õde maailma kultuurikeelte hulgas, peenejooneline ja mitmekülgne, mõnede inimkonna parimate kunstteoste kandja, omapärane ja üldinimlik ühtlasi, oo, keerulise ja painduva lauseõpi ja kõlavate lõppudega keel, imeväärselt varjundirikas, nõretav sõnust ja kõnekäändudest, triumfeeriv ja uhke, diskreet ja intiim, äratundmatu ja särav tütar, tõusnud orjaikkest kängu rõhut emast, oma kodust lõhna, maa-aroomi alal hoidev, kuid samal ajal literaarne ja kunstlik par excellence, sest suhtes ainulaadne maailmas, niisugusena kujutlen ja näen ja tervitan sind, oo tulevane parem eesti keel, parema tuleviku ja õnnelikuma, kaunima Eesti eeldus ning ehe! (Aavik 1924: 152).

Selle, Aavikult pärineva kujundkeele osatähtsust ühe keele arengus toonitava lõiguga, võib siinkohal lõpetadagi kõnekäänu-termini kujunemise algusperioodi lähivaatluse. Sõna, mis veel 20. sajandi alguseks ei olnud suutnud leida laiemat kasutust, võttis edaspidi sisse üha kindlama koha. Ka rahvakeelsete ütluste liigitamisega seotud temaatika pakkus uurijaile jätkuvalt huvi.

\section{Kokkuvõtteks}

Nagu eeltoodust näha, on eestikeelse kõnekäänu-termini kinnistumine olnud keerukas. Ühe põhjusena on võimalik näha omaaegses saksakeelses terminoloogias valitsenud segaduse mõju kohaliku kirjakeele arendajatele. See tõi endaga kaasa erinevad terminid ka eestikeelse samalaadse ainese kohta. Näiline iseseisvusetus ja seotus vanasõnadega suutis paraku jätta püsiväljendite terminitarvitusele jälje, mis oli visa kaduma ka järgnevatel aastasadadel. Selgust terminikasutuses ei järgnenud ka pärast Masingu poolt kõnekäänu-termini esitamist 1816. aastal. Alles Wiedemanni sõnaraamatu ilmumise järel saavutas kõnekäänd kindlakujulise terminina vähehaaval osatähtsuse sõnaraamatutes, õpikutes jm väljaannetes. Samas leidus veel 19. sajandi lõpul autoreid, kes samastasid kõnekäändu tühja väljendusega, pidurdades seesuguse, kohati üpris halvustava suhtumisega taas termini kinnistumist kasutuses. Ikka ja jälle eelistati rahvapäraste ütluste üldnimetusena vanasõna. 20. sajandi alguses võis kõnekäändu kohata aga üha enam, võrdväärselt teiste kujundlikke keeleüksuseid märkivate terminitega. Lisandusid ka uued oskussõnad, mis avardasid arusaamu kujundlike väljendite loomusest ja nende kohast ühes keeles. 


\section{Lisa 1. Püsiväljendeid märkivad eestikeelsed terminid 17.-20. sajandi kirjasõnas}

\begin{tabular}{|l|l|l|}
\hline 17.-18. sajand & 19. sajand & 20. sajandi algus \\
\hline lihck pajatus & kõnekäänd & rahvasõnad \\
liig könne & kõneviisid & rahvakeele ütlused \\
käänid ja väänid & kõnekombed & mõistukõnekäänud \\
kõnejätk & fraas \\
mõistusõna & fraseoloogia \\
vanasõnalised kõnekäänud & frastusõnalised kõnekäänud \\
sõnakõlks/kõnekõlks & \\
& & \\
& & \\
\hline
\end{tabular}

\section{Kommentaarid}

1 Artikli valmimist on toetanud Euroopa Liit Euroopa Regionaalarengu Fondi kaudu (Eesti-uuringute Tippkeskus), see on seotud Eesti Haridus- ja Teadusministeeriumi uurimisprojektidega IUT 22-5 ja EKKM 14-385.

2 Sõna tuleneb kreekakeelsest $\Phi \rho \dot{\alpha} \sigma r s$ ja tähendab 'kõne, väljendusviis' (VSL 2012).

3 Saksakeelse lingvistika- ja folkloristika-alase terminoloogia arenguloo üks parimaid allikaid on vendade Jakob ja Wilhelm Grimmi algatusel 1854. aastal ilmumist alustanud sõnaraamat "Deutsches Wörterbuch". Artiklis toodud saksakeelsed terminid on seal esitatud eri aegade esinemisjuhtudena.

${ }^{4}$ Ladinakeelse proverbium puhul tuleb näha seoseid Piibliga, täpsemalt Vana Testamendiga ja selles sisalduva raamatuga "Saalomoni Õpetussõnad" / "Saalomoni Tarkuse sõnad”, mille saksakeelsete nimetustena on käibel Buch der Sprüche, Sprüche Salomos, Buch der Sprichwörter (ehk Ütlemiste raamat, Saalomoni ütlemised, Vanasõnade raamat). Ladinakeelses "Vulgatas" kannab see raamat pealkirja liber proverbiorum Salomonis, lühendatult Proverbia. Esimeses eestikeelses piiblitõlkes (1739) on see raamat pealkirjastatud "Salomoni Öppetusse- ehk Wannad Sannad" (Piiblisõnastik 2017). Kreekakeelne $\pi \check{\alpha} \rho \mu_{\mu} \tilde{\grave{\alpha}}$ seevastu tähistab mitte üksnes vanasõna, vaid laiemalt ütlust.

5 Sõna pajatama loetakse vanavene või vene laenuks, tähendusega 'rääkima, loitsima'. Osutatud on ka soomekeelsele verbile pajattaa 'pajatada, vadrata, jahvatada' (ETY 2012).

6 Võrdluseks võib tuua, et samasuguse esiosisega termin liigusk märgib Stahlil ebausku (Ress 2009: 639).

7 Vt ka Krikmanni põhjalikku ülevaadet Vestringi käsikirjast (Krikmann 1986: 82-95).

8 Ariste hinnangul on see tähendus kasvanud välja rahvaetümoloogiast, milles on samastatud lick/liik ja liig (Ariste 1940: 40). 
9 Samasugusele tautoloogilisele kasutusele osutab ka Carl Schulze oma põhjalikus ülevaates vanasõna-alasest saksakeelsest terminoloogiast (1851: 378).

${ }^{10}$ Võrdlusena võib välja tuua, et varaseimatest saksakeelsetest vanasõnakogumikest olulisimaks peetav "Sybenhundert vnd Fünfftzig Teütscher Sprichwörter" pärineb reformatsiooniajast (1534), autoriks Johannes Agricola. Ta kasutas terminit Sprichwort ka tähenduses 'vana, esivanemate seas üldtuntud sõna' (Schulze 1851: 377). Võib vaid oletada, et ehk oli just Agricola teos selleks allikaks, mis võis mõjutada Stahli eestikeelse vaste loomisel.

${ }^{11}$ Seesugustest lokaalsetest keelenditest koostatud sõnaraamatuid tavatseti märkida sõnaga Idiotikon. Ka Hupel koostas selliselt pealkirjastatud sõnastiku, milles selgitab Liivi- ja Eestimaa saksa keelele iseloomulikke sõnu ja väljendid: "Idiotikon der deutschen Sprache in Lief- und Ehstland. Nebst eingestreueten Winken für Liebhaber" (osa raamatust pealkirjaga "Neue Nordische Miscellaneen", 1795).

${ }^{12}$ Käsikiri asub Eesti Kirjandusmuuseumi kirjandusloolise arhiivi käsikirjade osakonnas.

${ }^{13}$ Siinkohal toodud lõik pärineb publitseeritud kirjavahetuse eestikeelsest tõlkest (tõlkijaks Betti Alver) sooviga näidata tollaste kirjameeste huvi kujundliku keelekasutuse vastu rahvakeeles. Kirjade originaalid on säilitatavad Eesti Kirjandusmuuseumi kirjandusloolises arhiivis ning nende alusel selgitas siinkirjutaja välja termini saksakeelse esinemiskuju.

${ }^{14}$ Antud kirjakoha eestikeelses tõlkes on saksa Redensart vasteks kõnekäänd: Sinu pensum on: inimese keha, kõigi selle osade ja toimetuste leksikaalne kirjeldamine koos sõnade ja kõnekäändudega (Kreutzwaldi kirjavahetus 1976: 57).

${ }^{15}$ Siin võib oletada põhjusena 1864. aastal ilmunud teost "Wetter in Sprichwort", autoriks Otto von Reinsberg-Düringsfeld. Raamatu eessõnas kasutab ta terminit Bauernregel, märkimaks ilma kohta käivaid vanarahva ütlusi.

${ }^{16}$ Siinkohal toon ära käsitletava kirjakoha tõlke nagu see sisaldub Wiedemanni tegevust selgitavas kommentaaris, mille on lisanud Franz Anton Schiefneri kirjale Kreutzwaldiga kirjavahetuse toimetaja Mart Lepik. Wiedemanni aruande originaali leiab Venemaa Teaduste Akadeemia 1861. aasta bülletäänist (Wiedemann 1861).

${ }^{17}$ Andmaks aimu saadetiste mahust, toon siinkohal laekumised aastatest 1872-1875: rahvalaule 1076, jutte 189, mõistatusi 927, vanasõnu ja kõnekäände 3132 (Saukas 2004: 168). Nagu neist arvudest näha, on ütlusfolkloori osakaal märkimisväärne.

${ }^{18}$ Sama kirjatöö sisaldub ka Jakob Hurda keeletemaatilisi artikleid koondavas väljaandes "Jakob Hurt. Keelemees" (2012).

${ }^{19}$ Kunder toob punkti Mitmesugused sõna- ja kõnekujud all näiteid rahvapärastest nimetustest ja võrdlustest, kasutamata täpsemat terminit nende märkimiseks (1886: 231).

${ }^{20}$ Siinkirjutaja kasutab nimekuju Nebocat, s.t sellisel kujul, nagu see oli tema siinkohal vaadeldavate väljaannete tiitellehel.

${ }^{21}$ Võimalik, et Grenzstein on kasutanud allikana vene keeleteadlase Vladimir Dali monumentaalset teost vene rahva paröömiatest, mille esimene trükk ilmus 1862 (vt Krikmann 1997: 27-28). Selles toob ta ühe alaliigina скороговорка, mis esineb ka Grenzsteinil.

${ }^{22}$ Ainus erinevus nende kahe väljaande puhul seisneb pealkirjas. Uuesti trükiti tiitellehed, raamatu sisu on sama. 
${ }^{23}$ Sisaldab muuhulgas alajaotist "Ütles", mis koosneb ütluste alaliigiks peetavatest vellerismidest (vt ka Baran 2017).

${ }^{24}$ Võib oletada, et seesugune täpsustus on tehtud aasta varem ilmunud August Tõllasepa raamatu "Vanasõnad ilmadest" (1920) mõjul.

${ }^{25}$ Esmakordselt kasutas Eisen kõnekäänu-terminit oma brošüüris "Walekuld" (1902), küll määratlemata, mida ta täpselt selle all mõtleb.

${ }^{26}$ Selleks teoseks oli Johann Rudolph Sattleri “Teutsche Ortographey und Phraseologey" (1617).

${ }^{27}$ Bally teooria puhul on fraseologismide eristamisel kesksel kohal idiomaatilisuse mõiste. Termin idioma pärineb kreeka keelest ja tähendab iseärasust, eripära (VSL 2012). Fleischer toob esile selle esinemise varasemates saksakeelsetes võõrsõnaleksikonides, iseäranis Johann Christian August Heyse teoses "Allgememeines Fremdewörterbuch" (1804): Idiom "Eigenheit, Eigenthümlichkeit (bes. in Hinsicht der Sprache eines Landes), die Mundart, Sprachweise, Spracheigenheit, Sprechart (eines Landes), Landessprache', mida võiks tõlkida lühidalt kui ühel maal kõneldava keele või murde eripärasust. Sama tähistab ka juba eespool mainitud Idiotismus.

\section{Allikad}

Faehlmann 1843 = Fr. R. Faehlmann, kuuskümmend kaheksa kirja Fr. R. Kreutzwaldile. 13.I 1842-27. IX 1849. Eesti Kirjandusmuuseumi Eesti Kultuurilooline Arhiiv, f 63, m 1:1.

Kreutzwald, Friedrich Reinhold 1864. Vanasõnade kogu. Eesti Kirjandusmuuseumi Eesti Kultuurilooline Arhiiv, f 63, m 4:23.

\section{Kirjandus}

Aavik, Johannes 1924. Keeleuuenduse äärmised võimalused. Tartu: Istandik.

Agricola, Johannes 1534. Sybenhundert vnd Fünfftzig Teütscher Sprichwörter, verneüwert vnd gebessert. Frankfurt: Peter Braubach (https://archive.org/details/bub_ gb_ubhRAAAAcAAJ - 13. november 2017).

Ariste, Paul 1940. Georg Mülleri saksa laensõnad. Acta et Commentationes Universitatis Tartuensis (Dorpatensis). B Humaniora. Tartu: [Tartu Ülikool], lk 3-62.

Ariste, Paul 1971. Ferdinand Johann Wiedemann. Tartu: Tartu Riiklik Ülikool.

Ariste, Paul 1981. Keelekontaktid. Eesti keele kontakte teiste keeltega. Tallinn: Valgus.

Arndt, Johannes 1610. Vom wahren Christenthumb. Magdeburg: Francke, Böel (https:// epub.ub.uni-muenchen.de/5112/1/5112.pdf - 13. november 2017).

Baran, Anneli 1998. Kõnekäänd ja fraseologism - distinktsiooni võimalikkusest/vajalikkusest. Lohetapja. Pro Folkloristica VI. Tartu: Eesti Kirjandusmuuseum, lk 20-24 (http://www.folklore.ee/rl/pubte/ee/NT/profo6/Baran.htm - 13. november 2017). 
Baran, Anneli 2017. Vellerismist - ühest erilisest väikevormist. Methis. Studia Humaniora Estonica. Vabanumber 19, lk 31-52 (doi: 10.7592/methis.v15i19.13435).

Eesti keele õigekirjutuse-sõnaraamat 1918. Eesti Kirjanduse Seltsi wäljaanne. E.K.S. Keeletoimekonna toimetused 5. Tallinn: Rahvaülikooli kirjastus (http://www.etera.ee/ zoom/9460/view?page $=5 \& p=$ separate $\&$ view $=0,0,1921,2882-13$. november 2017 ).

Eisen, Matthias Johann 1902. Walekuld. Kujutused igapäewasest elust. Jurjev: Kristliku rahvakirjanduse agentuur.

Eisen, Matthias Johann 1913. Meie wanahõbe. Sarjatäis Eesti rahwa endist tarkust, kõnekäändusid ja ütlusi. M. J. Eiseni kogust. Tartu: Hermann (http://kivike.kirmus.ee/ meta/AR-17156-49183-23076 - 13. november 2017).

Eisen, Matthias Johann 1914. Eesti wanadsõnad. Suurest korjandusest kokku põimitud. Tartu: K. Sööt ja G. Roht (http://www.digar.ee/arhiiv/nlib-digar:37548 - 1. juuli 2017).

ETY 2012 = Metsmägi, Iris \& Sedrik, Meeli \& Soosaar, Sven-Erik (koost). Eesti etümoloogiasõnaraamat. Tallinn: Eesti Keele Instituut (http://www.eki.ee/dict/ety/ 13. november 2017).

Fleischer, Wolfgang 1997. Phraseologie der deutschen Gegenwartssprache. 2., durchgesehene und ergänzte Auflage. Tübingen: Max Niemeyer Verlag.

Gottsched, Johann Christoph 1762. Vollständigere und neuerläuterte deutsche Sprachkunst, nach den Mustern der besten Schriftsteller des Vorigen und itzigen jahrhunders abgefasset, und bey dieser fünften Auflage merklich verbessert. Leipzig: verlegts Bernard Christoph Breitkopf (https://babel.hathitrust.org/cgi/pt?id=nyp.334330825109 87; view=1up;seq=9 - 13. november 2017).

Grenzstein, Ado 1884. Eesti Sõnaraamat.1600 uut ja wõerast sõna. Korjanud ja (Saksa sõna lisandusega) Eesti keeles selgitanud A. Grenzstein. Tartu: A. Grenzstein (http:// www.digar.ee/arhiiv/nlib-digar:101413 - 13. november 2017).

Grenzstein, Ado 1887. Eesti Lugemise-raamat. Esimene jagu. Tartu: A. Grenzstein (http:// www.digar.ee/arhiiv/nlib-digar:100052 - 13. november 2017).

Grenzstein, Ado 1888. Eesti Lugemise-raamat. Teine jagu. Tartu: A. Grenzstein (http:// www.digar.ee/arhiiv/nlib-digar:100068 - 13. november 2017).

Grenzstein, Ado 1890. Riigikeele õpiraamat Eestlastele. Kolmas jagu. Tartu: A. Grenzstein (http://www.digar.ee/arhiiv/nlib-digar:110040 - 13. november 2017).

Grenzstein, Ado 1899. Kauni keele kaitsemiseks. Jurjev: A. Grenzstein.

Grimm, Jacob \& Wilhelm 1854. Deutsches Wörterbuch. 16 Bde. in 32 Teilbänden. Leipzig 1854-1961 (http://woerterbuchnetz.de/cgi-bin/WBNetz/wbgui_py?sigle=DWB\&mode=V ernetzung\&lemid=GP04683\#XGP04683 - 13. november 2017).

Gutslaff, Johannes 1998. Lepajõe, Marju (koost) \& Peebo, Jaak (toim). Observationes grammaticae circa linguam Esthonicam. Grammatilisi vaatlusi eesti keelest. Tartu: Tartu Ülikool.

Göseken, Heinrich 1660. Manuductio ad Linguam Oesthonicam, Anführung zur Öhstnischen Sprache, Bestehend nicht alleine in etlichen praeceptis und observationibus, Sondern auch In Verdolmetschung vieler Teutschen Wörter. Reval: A. Simon (http:// www2.kirmus.ee/grafo/index.php?ID=243 - 13. november 2017). 
Habicht, Külli \& Penjam, Pille \& Prillop, Külli 2015. Heinrich Stahli tekstide sõnastik. Kingisepp,Valve-Liivi (toim). Tartu: Tartu Ülikooli Kirjastus.

Helle, Anton Thor 1732. Kurtzgefaszte Anweisung Zur Ehstnischen Sprache, in welcher mitgetheilet werden I. Eine GRAMMATICA. II. Ein VOCABULARIUM. III. PROVERBIA. IV. AENIGMATA. V. COLLOQUIA. Halle: S. Orban (http://www.digar.ee/arhiiv/nlibdigar:100071 - 13. november 2017).

Hermann, Karl August 1884. Eesti keele Grammatik. Koolide ja iseõppimise tarvis kõikidele, kes Eesti keelt õigesti ja puhtasti kõnelema ja kirjutama ning sügavamalt tundma ja uurima tahavad óppida. Tartu: W. Just (http://www.digar.ee/arhiiv/nlibdigar:100069 - 13. november 2017).

Hermann, Karl August 1889. Täieline Eesti-Wene sõnaraamat. Tartu: K. A. Hermann (http://www.digar.ee/arhiiv/nlib-digar:111179 - 13. november 2017).

Heyse, Johann Christian August 1804. Allgemeines Wörterbuch zur Verdeutschung und Erklärung der in unserer Sprache gebräuchlichen fremden Wörter und Redensarten: zum bequemen Gebrauch für Alle, welche jene Ausdrücke richtig verstehen und gebrauchen, oder auch vermeiden wollen, insonderheit für Schulen. Oldenburg: Schulze (http://reader. digitale-sammlungen.de/de/fs1/object/display/bsb10797549_00005.html - 13. november 2017).

Hupel, August Wilhelm 1780. Ehstnische Sprachlehre fuer beide Hauptdialekte, den revalschen und doerptschen. Riga, Leipzig: J. F. Hartknoch (http://www.digar.ee/arhiiv/ nlib-digar:100926 - 13. november 2017).

Hupel, August Wilhelm 1795. Neue Nordische Miscellaneen. Eilftes und zwölftes Stück. Riga: Hartknoch (http://dspace.ut.ee/handle/10062/10492 - 13. november 2017).

Hurt, Jakob 1871a. Kas eesti keelele uusi sõno tarvis. Eesti Postimehe Lisaleht 22, 2. juuni, lk 130 .

Hurt, Jakob 1871b. Mis lugu rahva mälestustest pidada. Eesti Postimehe Lisaleht 26, 30. juuni, lk 153-154.

Hurt, Jakob 1875. Eesti Kirjameeste Seltsi protokollid. Kaheksas koosolek. 26. ja 27. septembril, Tartus. Eesti Kirjameeste Seltsi aastaraamat 1875. Tartu, lk 96-103 (http:// www.etera.ee/zoom/1182/view?page $=7 \& \mathrm{p}=$ separate $\&$ view $=0,0,2041,3402-13$. november 2017).

Hurt, Jakob 1888. Paar palwid Eesti ärksamaile poegadele ja tütardele. Olevik 9, 29. veebruar, lk 1 .

Hurt, Jakob 2012. Peebo, Jaak \& Runnel, Hando (koost). Keelemees. Tartu: Ilmamaa.

Jakobson, Carl Robert 1867. Kooli lugemise raamat. Esimene jagu. 80 pildiga. Tartu: H. Laakmann (http://www.digar.ee/arhiiv/nlib-digar:100504 - 13. november 2017).

Jakobson, Carl Robert 1875. Kooli lugemise raamat. Teine jagu. 46 pildiga. Tartu: H. Laakmann (http://www.digar.ee/arhiiv/nlib-digar:100092 - 13. november 2017).

Jakobson, Carl Robert 1876. Kooli lugemise raamat. Kolmas jagu. 40 pildiga. Tartu: H. Laakmann (http://www.digar.ee/arhiiv/nlib-digar:100085 - 13. november 2017). 
Johanson-Pärna, Jakob 1885. Wene-Eesti Sõna-raamat. 16 tuhat Wenekeele sõna. Tallinn: H. Mathiesen (http://www.digar.ee/arhiiv/nlib-digar:101465 - 13. november 2017).

Kampmann, Mihkel 1905. Kooli Lugemiseraamat. Esimene jagu. I-III. kooliaasta. 134 pildiga. Tallinn: K. Busch (http://www.digar.ee/arhiiv/nlib-digar:101888 - 13. november 2017).

Kampmann, Mihkel 1907. Kooli Lugemiseraamat. Teine jagu. 45 pildiga. Tallinn: A. Busch (http://www.digar.ee/arhiiv/nlib-digar:101724 - 13. november 2017).

Kampmann, Mihkel 1912. Eesti kirjanduseloo peajooned. 1 jagu. Tallinn: A. Busch (http:// www.etera.ee/zoom/1108/view?page $=5 \& p=$ separate $\&$ view $=0,0,1943,3113-13$. november 2017).

Kapp, Joosep 1873. Vana-sõna. Eesti Kirjameeste Seltsi aastaraamat 1873. Tartu, lk 3543 (http://www.etera.ee/zoom/1196/view?page=7\&p=separate\&view=0,0,2031,3394 13. november 2017).

Kibbermannn, Elisabeth \& Kirotar, Salme \& Koppel, Paula 2007. Saksa-eesti sõnaraamat. Deutsch-Estnisches Wörterbuch. Tallinn: Valgus.

Kreutzwald $1953=$ Fr. R. Kreutzwaldi kirjavahetus III. Fr. R. Kreutzwaldi ja A. Schiefneri kirjavahetus, 1853-1879. Tallinn: Eesti Riiklik Kirjastus.

Kreutzwald $1956=$ Fr. R. Kreutzwaldi kirjavahetus II. Kirjad A. H. Neusile, E. Sachssendahlile ja teistele. Tallinn: Eesti Riiklik Kirjastus.

Kreutzwald $1959=$ Fr. R. Kreutzwaldi kirjavahetus IV. Kirjad G. Schultz-Bertramile ja teistele, 1859-1874. Tallinn: Eesti Riiklik Kirjastus.

Kreutzwald $1976=$ Fr. R. Kreutzwaldi kirjavahetus I. Kirjad Fr. R. Faehlmannile, D. H. Jürgensonile ja teistele, 1833-1866. Tallinn: Kirjastus Eesti Raamat.

Krikmann, Arvo 1986. Fraseoloogiline aines eesti vanimais grammatikates ja sõnastikes. Tallinn: Valgus.

Krikmann, Arvo 1992. Fraseoloogilisi elemente Georg Mülleri jutlustes. Keel ja Kirjandus 3, lk 144-150.

Krikmann, Arvo 1997. Sissevaateid folkloori lühivormidesse I. Põhimõisteid, žanrisuhteid, üldprobleeme. Tartu: Tartu Ülikooli Kirjastus (http://www.folklore.ee/ kriku/LEX/ KATUS.HTM - 13. november 2017).

Krikmann, Arvo 1999. Eesti lühivormide allikaloost. Tartu: Eesti Keele Instituut (http:// www.folklore.ee/ kriku/ALLIK/laiindex.htm - 13. november 2017).

Krikmann, Arvo 2006. Tekstide päritolust ja rahvaehtsusest Kreutzwaldi vanasõnade ja kõnekäändude käsikirjas. Ettekanne Akadeemilise Rahvaluule Seltsi koosolekul 22. veebruaril 2006 (https://www.academia.edu/4630122/Tekstide_p\%C3\%A4ritolust_ ja_rahvaehtsusest_Kreutzwaldi_vanas\%C3\%B5nade_ja_k\%C3\%B5nek\%C3\%A4\%C3\% A4ndude_k\%C3\%A4sikirjas - 1. juuni 2017, ei ole enam kättesaadav).

Kunder, Juhan 1886. Mõnda Eesti rahva luuletusest. Eesti Kirjameeste Seltsis 17. juunil 1886 peetud kõne. Meelejahutaja 29, lk 230-231. 
Kuusik, Timotheos 1900. Wene-Eesti ja Eesti-Wenekeelne sõnaraamat. Tallinn: K. Busch. Kuusik, Timotheos 1903. Wene-Eesti ja Eesti-Wene sõnaraamat. Tallinn: K. Busch.

Körber, Carl 1869. Wanna rahwa moistusse könned ja targad sannad. Tartu: H. Laakmann (http://dspace.ut.ee/handle/10062/47612 - 14. november 2017).

Masing, Otto Wilhelm 1816a. Ehstnische Originalblätter für Deutsche. Dorpat: J. C. Schünmann (http://www.digar.ee/arhiiv/nlib-digar:100235 - 14. november 2017).

Masing, Otto Wilhelm 1816b = Anvelt, Leo \& Aaver, Eva \& Laanekask, Heli \& Nagelmaa, Abel (koost) 1995. Otto Wilhelm Masingu kirjad Johann Heinrich Rosenplänterile 1814-1832. Esimene köide 1814-1818. Tartu: Eesti Kirjandusmuuseum.

Muuk, Elmar \& Tuksam, Georg 1941. Väike saksa-eesti sõnaraamat. Tartu: Teaduslik Kirjandus.

Nebocat, Jaan 1884. "Kündja”. Eesti keeleõpetus nenda kui Eestikeelt Kesk-Eestimaal räägitakse. E. Ahrens’i ja Dr. F. J. Wiedemann’i järel väljaannud J. Nebocat. Tartu \& Riia: Schnakenburg (http://www.digar.ee/arhiiv/nlib-digar:100476 - 14. november 2017).

Nebocat, Jaan 1885. Saksa-Läti-Vene-Eestikeele Sõnaraamat = Cистелатический словарь немецкого, латышского, русского и эстонского языков = Systematisches Vocabularium in deutscher, lettischer, russischer und estnischer Sprache $=$ Sistematiski sakahrtota Wahzu-Laweeschu-Kreevu-Igaunu wahrdniza. Tartu \& Riia: Schnakenburg (http://www.digar.ee/arhiiv/nlib-digar:101182 - 14. november 2017).

Nebocat, Jaan 1889. Eesti-Saksakeele Sõnaraamat selge kirja- ja kodukeele = Estnisch Deutsches Wörterbuch der höheren Schrift- und Umgangssprache. Riia \& Tartu: Schnakenburg.

Niggol, Carl Heinrich 1876. Vene keele õppimise raamat. Tartu: C. Mattiesen (http:// www.digar.ee/arhiiv/nlib-digar:102060 - 14. november 2017).

Normann, Erna 1959. Vanasõnad J. Ch. Clare eesti-saksa sõnaraamatus. Emakeele Seltsi aastaraamat V, lk 18-40.

Nurmik, Madis 1920. Eesti Kooli Esimene lugemik. Tallinnas: Eestimaa Kooliõp. V. A. Seltsi raamatukauplus.

Nurmik, Madis 1921. Teine lugemik. Tallinn: Kool.

Nurmik, Madis 1923. Esimene lugemik. Kolmas trükk. Tallinn: Tallinna Eesti KirjastusÜhisus.

Piiblisõnastik 2017 = Eesti piiblitõlke ajalooline konkordants (https://www.eki.ee/ piibel/index.php?tegevus=viewbibletext\&showversion=3\&showbook=1Ms\&done=1 14. november 2017).

Raag, Raimo 2008. Talurahva keelest riigikeeleks. Tartu: Atlex.

Reinsberg-Düringsfeld, Otto von 1864. Das Wetter im Sprichwort. Leipzig: Hermann Fries.

Ress, Kristel 2009. XVII sajandi saksa-eesti sõnastike töötlemise probleemidest. Keel ja Kirjandus 8-9, lk 631-641. 
Ross, Kristiina 2005. Algkmesest lõpmatusse kulgevad keeleuuenduste kurvid. Keel ja Kirjandus 7, lk 521-525.

Salem, Margus 1890. Eesti-Wene sõnaraamat Wiedemanni järele. Tallinn: T. Jakobson (http://www.digar.ee/arhiiv/nlib-digar:101674 - 14. november 2017).

Sander, Tõnu 1899. Eesti kirjanduse ajalugu. I jagu. Rahvaluule. Jurjew (Tartu): Sööt (http://kivike.kirmus.ee/meta/AR-15125-59998-66541 - 14. november 2017).

Sarv, Ingrid 1964. Eesti vanasõnade ja kõnekäändude publitseerimisest ning uurimisest. Pino, Veera \& Tedre, Ülo \& Viidalepp, Richard (toim). Eesti rahvaluulest = Об эстонском фольклоре. Tallinn: ENSV Teaduste Akadeemia, lk 97-125.

Sattler, Johann Rudolph 1617. Teutsche Ortographey und Phraseologey, dz ist ein underricht Teutsche sprach recht zu schreiben. Basel: Ludwig König (http://reader.digitalesammlungen.de/de/fs1/object/display/bsb10584293_00005.html - 14. november 2017).

Saukas, Rein 2004. Mõistatuste kogumine Eesti Kirjameeste Seltsis aastatel 1872-1893. Mäetagused 26, lk 161-194 (doi: 10.7592/MT2004.26.saukas).

Schmitz, Bernhard 1872. Deutsch-französische Phraseologie in systematischer Ordnung. Ein Übungsbuch für Jedermann, der sich im freien Gebrauche der französischen Sprache vervollkommnen will. Greisswald: M. Bamberg (http://reader.digitale-sammlungen.de/ de/fs1/object/display/bsb11010171_00005.html - 14. november 2017).

Schottel, Justus Georg 1663. Ausführliche Arbeit Von der Teutschen HaubtSprach. Braunschweig: Zwilliger (http://reader.digitale-sammlungen.de/resolve/display/bsb10523348. html - 14. november 2017).

Schulze, Carl 1851. Ausdrücke für Sprichwort. Zeitschrift für deutsches Alterthum 8. Berlin: Weidmann, lk 376-384.

Seiler, Friedrich 1922. Deutsche Sprichwörterkunde. München: Beck (https://archive. org/details/deutschesprichw00seiluoft - 14. november 2017).

Stahl, Heinrich 1637. Anführung zu der Esthnischen Sprach, auff Wolgemeinten Rath, und Bittliches Ersuchen. Reval: C. Reusner (http://www.digar.ee/arhiiv/nlib-digar:101060 14. november 2017).

Stein, Victor Julius 1875. Üks kubu Wanu-sõnu ja wanu kõnekombeid. Tartu: H. Laakmann.

Stieler, Kaspar von 1691. Der teutschen Sprache Stammbaum und Fortwachs. Nürnberg: Hofmann (http://reader.digitale-sammlungen.de/de/fs1/object/display/bsb11069100_00005. html - 14. november 2017).

Tõllasepp, August 1920. Vanasõnad ilmadest. Tallinn: Rahvaülikool.

Veski, Johann Voldemar (toim) 1925. Eesti õigekeelsuse-sõnaraamat. "Eesti keele õigekirjutuse-sõnaraamatu” II täiendatud ja parandatud trükk. Tartu: Eesti Kirjanduse Seltsi kirjastus. (http://www.etera.ee/zoom/7967/view?page=5\&p=separate\&vi ew $=0,0,1898,3148-14$. november 2017).

Vestring, Salomo Heinrich 1998. Kaldjärv, Ellen (toim). Lexicon Esthonico Germanicum. Eesti-saksa sõnaraamat. Tartu: Eesti Kirjandusmuuseum (http://www.folklore.ee/ kriku/ VESTRING/ - 14. november 2017). 
Wiedemann, Ferdinand Johann 1861. Erster Bericht über eine zu linguistischen Zwecken unternommene Reise in Ehst- und Livland. Bulletin de l'Académie Impériale des Sciences de St.-Pétersbourg IV, lk 299-303 (https://babel.hathitrust.org/cgi/pt?id=mdp.39015084 467474;view=1up;seq=7 -14. november 2017).

Wiedemann, Ferdinand Johann 1869. Estnisch-Deutsches Wörterbuch von F. J. Wiedemann. St. Petersburg: Kaiserliche Akademie der Wissenschaften (https://babel.hathitrust.org/ cgi/pt?id=inu.30000118739998;view=1up;seq=7 - 14. november 2017).

Wiedemann, Ferdinand Johann 1876. Aus dem inneren und Äusseren Leben der Ehsten. St.-Petersburg [etc]: Eggers et Co., H. Schmitzdorff, J. Issakof und A. Tscherkessof [et al] (http://www.folklore.ee/rl/pubte/ee/vanad/aiale/ - 14. november 2017).

Wiedemann, Ferdinand Johann 1973. Eesti-saksa sõnaraamat. Estnisch-Deutsches Wörterbuch. Neljas, muutmata trükk teisest, Jakob Hurda väljaandest. Tallinn: Valgus.

VSL 2012 = Vääri, Eduard \& Kleis, Richard \& Silvet, Johannes \& Paet, Tiina \& Rehemaa, Tuuli. Võõrsõnade leksikon 8., põhjalikult ümber töötatud trükk. Eesti Keele Instituut (http://www.eki.ee/dict/vsl/vsl.html - 14. november 2017).

Õim, Katre 2005. Fraseologism versus kõnekäänd. Erelt, Mati (toim). Emakeele Seltsi aastaraamat 50 (2004). Tallinn: Emakeele Selts, lk 129-142 (http://www.emakeeleselts. ee/esa/ESA_50_pdf/Oim.pdf - 14. november 2017).

Õim, Katre \& Õim, Asta 2011. Eesti fraseoloogia leksikograafiline areng. Keel ja Kirjandus 11, lk 842-862 (https://keeljakirjandus.eki.ee/842-862.pdf - 14. november 2017).

\title{
Summary
}

\section{Evolution of the Estonian term kõnekäänd}

\author{
Anneli Baran \\ Senior Research Fellow \\ Department of Folkloristics, Estonian Literary Museum \\ anneli@folklore.ee
}

Keywords: dictionary, German language, proverb, saying, short forms of folklore, textbooks, written language

Phrasemes that represent a short folklore genre are found in all languages. They can be used to enrich both the spoken and written language, and the ability to use them shows a skilful mastery of the language. The term kõnekäänd [speech + turn $>$ turn of phrase], which marks instances of figurative language, first appeared in Estonian a couple of centuries ago. The present article explores written Estonian sources (dictionaries, grammars, textbooks, handbooks, and monographs, but also correspondence and handwritten collections) from the 17 th century up to the $1920 \mathrm{~s}$, to find out how this term evolved and why it came into use. In so doing, some insights into German terms are also offered to explain the influence other languages had on the written language that was still developing back then. 